\title{
Město a společnost. Kutná Hora v dlouhém 14. století
}

\author{
Town and Society. Kutná Hora during the long 14th Century
}

\author{
Blanka Altová
}

\begin{abstract}
The text focuses on the ties between society and the urban development of the Royal mining town of Kutná Hora [from the perspective of the history of Art] during the period of the last two decades of the $13^{\text {th }}$ century, up to the beginning of the Hussite Revolution in the early decade the $15^{\text {th }}$ century. It mainly focuses on well-preserved architectectural objects and their appearance and relationship in the urban context of the historical town core. The town was formed on Sedlec Cistercian Church land under the patronage of the King, but the decisive social entity that determined the appearance and significance of the town were mining entrepreneurs of patrician origin - miners. For four generations, they formed the image of a town in which they could live and work, but at the same time express the position which they hoped to achieve within medieval feudal society. Identification of this social entity with the name and location of their working activity, and the source of their status and wealth, was typical and is in my analysis the key point interpreting of the urban and social perspective of Kutná Hora and its' particular components. The image of town and society which I focus on has its own composition, structure, hierarchy, function, form and content, as well as its own historical and aesthetic value, subsistence and existential significance.
\end{abstract}

KEY WORDS generations, history of art, image of town, Kutná Hora, society of town

\section{Úvod}

V předložené stati bych chtěla sledovat vazby mezi společenským a urbanistickým vývojem Kutné Hory v předhusitském období, tedy v „dlouhém 14. století“. Přesněji, vymezené období v sobě zahrnuje poslední desetiletí 13. století, kdy bylo zřejmé, že Kutná Hora aspiruje na to stát se královským městem, až do počátku 15. století, kdy se uzavírá velkorysá stavební aktivita městského patriciátu před vypuknutím husitských válek. Vycházím z př́stupu dějin umění k této problematice a chci se pokusit interpretovat strukturu půdorysu, rozvrh významných sakrálních staveb a obytné zástavby města jako zobrazení představ společenské skupiny, která město vytvářela a identifikovala se s ním. Takováto interpretace by mohla pomoci blíže charakterizovat onu skupinu a její cíle.

Pro uvedené období lze však obtížně rekonstruovat celistvý obraz města. V historickém jádru Kutné Hory nebylo zatím možné provádět soustavný archeologický průzkum, ${ }^{1}$ ale pouze průzkumy dílčí (záchranné), pro toto období je také nedostatek písemných pramenů. Přesto se pokouším

Sociální studia. Fakulta sociálních studií Masarykovy univerzity, 2/2006. S. 173-199. ISSN 1214-813X.

1 Vzhledem k navážkám terénu v průběhu a zániku dolování a stálému osídlení jádra. 


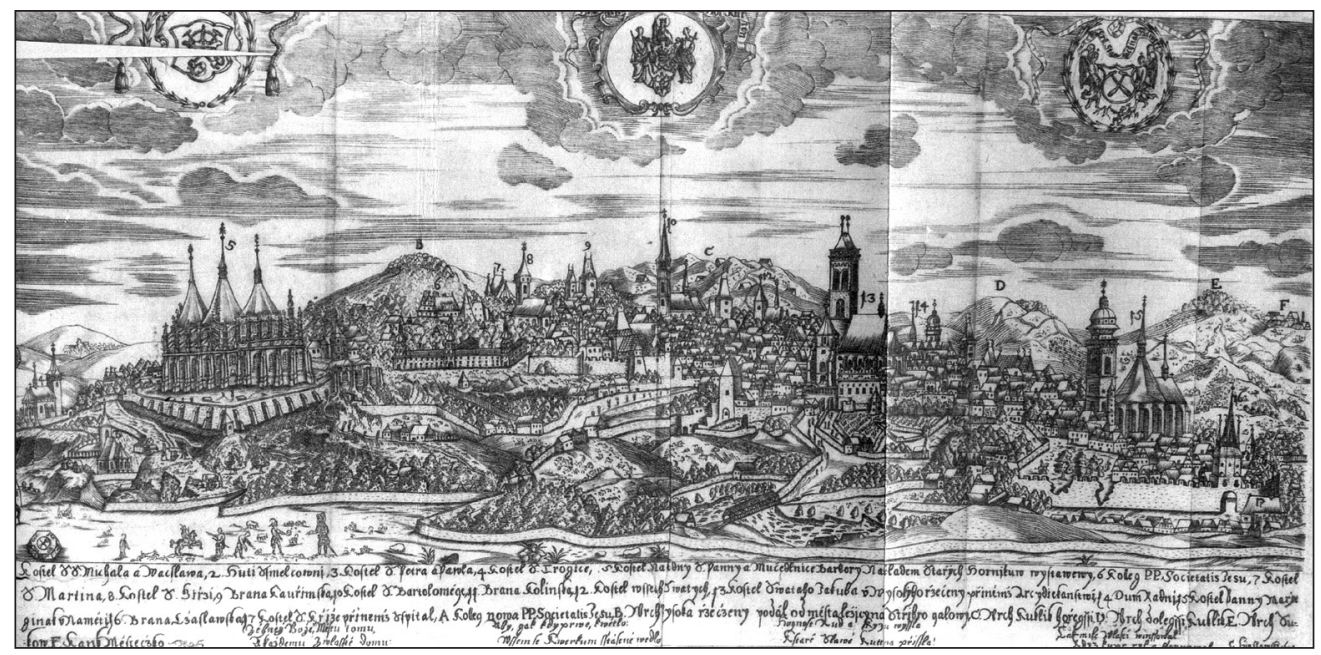

Obr. 1: Veduta Kutné Hory z přelomu 16. a 17. století od Jana Willenberga, kterou překreslil Jiří Čáslavský pro vydání (1675) Starých pamětí kutnohorských Jana Kořínka. Zdroj: archiv autorky.

s pomocí poznatků vyplývajících ze sporadických pramenů a na základě historických analogií formulovat, jaké představy mohli obyvatelé města spojovat s jeho podobou a fungováním. Vycházím ze současného obrazu města, ve kterém významovou osnovu, k níž se vztahovaly a vztahují všechny důležité prvky města, tvoří sakrální stavby z předhusitského období (Lynch 2004: 46n.). Smysl života jedince jako součásti společnosti se ve středověku komplexně objasňoval v oblasti náboženské. Na tvorbu obrazu města měla tedy zásadní vliv církev, v případě Kutné Hory reprezentovaná představiteli cisterciáckého kláštera $\mathrm{v}$ Sedlci, ${ }^{2}$ kteří prostřednictvím malínské fary vykonávali patronátní právo nad kaplemi na svých pozemcích, na nichž se rozrůstaly hornické osady a pozdější město Kutná Hora. Zatímco kostely a jejich obrazivost působí v urbanistickém celku dodnes bez výraznějších změn, podoba a struktura profánní zástavby města se měnila (zanikala) rychleji. U staveb veřejných, obytných i hospodářských jejich užitná funkce více či méně převažovala nad jejich obrazivostí, mají tedy nesporný význam pro „historický“ obraz města, nikoli však pro obraz „,estetický“، Z estetického hlediska jsou sakrální stavby už svým účelem zobrazující - umělecké -, protože konkretizují obecně sdílené představy společnosti o sobě samé a o obraze světa, který si vytvořila. Ze středověkého hlediska to byly symboly, dnes jsou uznávána jako umělecká díla ${ }^{3}$ a tvoří tedy nejen základní kompoziční, ale i obsahovou strukturu obrazu města, který chci v tomto článku přiblížit. Do jeho „kamenné“ podoby se pokouším vnést dynamiku pomocí poznatků o mentalitě „středověkého člověka“. Vím, že jeden konstrukt oživuji dalším konstruktem, a tím i umocňuji rizika takového postupu, ale nemohu odolat této možnosti, protože v ní vidím způsob, jak lépe porozumět tomu, co vidím a vím. Neskrývám se tedy ani za autorský plurál, neprezentuji svou studii jako definitivní závěr výzkumu, ale vnímám ji jako jeho součást.

2 Cisterciácký klášter v Sedlci založen v roce 1142.

3 Význam pojmů „umělecké dílo“, „uznání“ uměleckého díla, „historický“, „estetický“ viz např. Brandi (2000). 
Rekonstrukce podoby předhusitské Kutné Hory je komplikovaná, protože se nachází pod pozdějšími historickými sedimenty. Avšak porozumět v čase narůstajícímu obrazu města bez pochopení této spodní podkladové vrstvy není možné. Př̌i studiu jakékoli další historické fáze fungování města odborníci různého zaměření většinou konstatují, že zůstal zachován původní koncept města, že nadále ovlivňuje společenskou strukturu a kulturu města apod. To se ale týká faktického obrazu města, který je fixován $\mathrm{v}$ jeho půdorysu, urbanistické scéně, v podobě a uspořádání jednotlivých architektonických objektů a v systému komunikací atd., ale také v místních názvech a v písemných i obrazových pramenech.

Tomuto faktickému obrazu ovšem musel předcházet, a s ním se pak zároveň dotvářet, obraz města $\mathrm{v}$ mysli lidí, kteří ono město nejdř́ve koncipovali, postupně realizovali a spolu s dalšími užívali a identifikovali se s ním. Tento obraz vyplývá z interpretace hmotných i písemných pramenů a zejména ze zkušenosti, kterou člověk získá jako obyvatel nebo návštěvník města. Pochopili ho a jako závazný přijali noví obyvatelé, kteří vytvořili základy nové městské společnosti utrakvistické Kutné Hory ve třicátých letech 15 . století, a pak i všechny následující generace Kutnohořanů až po tu současnou. Dlouhé 14. kutnohorské století se stalo „zlatým časem“ města, $\mathrm{k}$ němu se vraceli a s ním poměřovali všichni, kteří se s městem veřejně identifikovali, i když už žili v odlišných ekonomických, ideologických, politických a společenských podmínkách. Zajímá mne právě vazba mezi faktickým a pomyslným obrazem, prolínání existenčního a existenciálního. Sleduji i setrvačnost takto vzniklého prvního obrazu města a její př́činy i jeho přesun z každodenního života do oblasti sváteční kultury.

Domnívám se, že právě význam zmíněného prvního obrazu města je hlavní příčinou retrospektivního trendu, který se v umění Kutné Hory projevuje od druhé poloviny 15. století a sílí od 16. století, kdy Kutná Hora postupně ztrácela charakter významného královského báňského města a sídla státní mincovny. Tendenční historismus zaměřený na předhusitskou dobu rozkvětu města se stal i podstatnou linií rekatolizačního programu v 17. až 18. století. V té době se zrodil „staroslavný“ obraz města jako významného místa české národní minulosti; pojmy „,̌eský“ a „národní“ byly vnímány ve vazbě na místo, nikoli jazyk, a „minulost" měla spíše význam kvantitativní než faktografický (vědecký). Historické stáří a výčet mimořádných osobností a událostí se staly měřítkem významu města (čím starší a významnější, tím lepší). Z tohoto „staroslavného“ obrazu města se postupně od osmdesátých let 19. století stával i politický argument, dokonce i program, který se pak měnil podle toho, jaká strana se ho zmocnila. Zároveň $\mathrm{s}$ fenoménem národních poutí $\mathrm{v}$ době obrozenecké začíná i turistický zájem o město a jeho minulost, který postupně nabývá až povahy mýtu a získává i komerční význam.

Akademický pohled na minulost Kutné Hory se odvijí ze stejného východiska jako „staroslavný“ obraz města, tedy především ze Starých pamětí kutnohorských jezuity Jana Kořínka (1675, kritické vydání Stich a Lunga 2000), a je možné ho sledovat ve všech historiografických směrech a v celém spektru historických věd, protože Kutná Hora není místem pouze lokálního významu ani po zániku dolování a mincování, ale právě pro svůj vztah k minulosti je stále v centru zájmu historiků. Ve 20. století to už nebyly jednotlivé architektonické objekty a artefakty, které budily pozornost historiků, ale město jako historický, umělecký a památkový celek. V roce 1952 byla Kutná Hora prohlášena za městskou památkovou rezervaci a v roce 1991 byla zapsána kvůli svému jedinečnému panoramatu do seznamu kulturních památek UNESCO. 
Je však pozoruhodné, jak je neustále se prohlubující a rozšiřující se „vědecký“ obraz města v každodenní praxi setrvale konfrontován s oním „staroslavným“ obrazem v mysli představitelů města a jedinců i institucí, kteří do jeho podoby zasahují a pro které se mnohdy stal dokonce i estetickou normou. ,Vědecký obraz“ se s poznáním proměňuje, ze své povahy nikdy nebude definitivní, kdežto „staroslavný“ obraz je obrazem v mysli, stal se trvalou uměleckou a nakonec i vědeckou inspirací (provokací). Výklad historie města je neustále velice živým a citlivým tématem, a to jak na vědecké, tak zejména na populární úrovni, a zůstává zároveň i politickou záležitostí. Obohacuje i omezuje současný život města, přitom mu ale dodává na významu bez ohledu na obvyklé dobové ukazatele a měřítka rozvoje. Projevuje se i v silném vztahu obyvatel k dějinám města, v míře jejich identifikace s místem, avšak zároveň i v přeceňování a zkreslování jeho minulosti na úkor současnosti. I současnost se poměruje s faktickou silou prvního obrazu města, ale is jeho mýtem.

\section{Středověké město v kontextu dějin spásy}

Lidé, kteří rozhodovali o založení města a ovlivňovali podobu jeho formujícího se obrazu, si museli být vědomi toho, že koncepcí půdorysu i podobou monumentální architektury se dá vytvořit a zhmotnit historia a fama města. Historia je chápána jako sled významných činů (které se mohly a nemusely stát) a fama je výkladem těchto činů (Bažant 2000: 1-2). Založení středověkého města i každého jednotlivého objektu je vnímáno také jako čin, který má širší význam, než poskytnutí střechy nad hlavou, a musí ho provázet fama, která mu dává vyšší smysl. Fama se projevuje v obrazivosti města i jeho jednotlivých objektů.

Středověká křest'anská společnost sama sebe vnímala jako obec a spojovala tuto představu s obrazem města. Každá pozemská obec měla být odleskem představy o obci Boží, a tedy i odleskem nebeského města (Sv. Augustin: $O$ Boži obci). Tato představa se promítala jak do usporádání městského celku, tak do uspořádání sakrálních staveb a do jejich vzájemné vazby. Vztah pozemské a Boží obce vycházel z konceptu dějin spásy, které se odvíjejí v jedné linii (jako cesta) od stvoření světa k jeho konci a směřují ke vzkř́išení, Poslednímu soudu a bud' k věčnému životu v nebeském městě, nebo k věčným mukám v pekle. Lidský život tvoří pouhý úsek této cesty a závisí na Boží milosti. O tom, zda bude člověku dána Boží milost, se každý křest’an dozví až u Posledního soudu. Znamením Boží milosti pro člověka může být víra, a proto se tolik úsilí věnovalo posilování víry a zdůrazňování jejího významu. Nejen středověký kostel, ale i středověké město byly prostory víry a oba tyto obrazy byly spojovány s představou cesty $\mathrm{k}$ Bohu. Kostely měly vytvářet ve městě pravidelnou sít’ a výrazné vertikály (dominanty) nad jednotnou městskou zástavbou. Dávaly městu vyšší řád. Byly propojené jak faktickými cestami, tak cestami pohledovými i akustickými (zvony).

Ve středověkém kontextu dějin spásy však nefiguroval člověk jako jedinec, ale jako př́slušník obce, která nesla kolektivní tíhu prvotního hříchu a nejistotu naděje na spásu. V obraze středověkého města se to projevovalo jednotnou koncepcí domovní zástavby. Domy vznikaly natěsnány jeden na druhý na jednotně stanovených úzkých parcelách, vyrůstaly do stejné výšky a řadily se do bloků podél ulic a prostranství. Domovní bloky tvořily i sousedské vztahy, tedy společenské vazby a všechno, co z nich ve středověkém městě vyplývalo: pocit bezpečí, potřeba obrany, povinnost přátelství, každodenní vzájemnost apod. „Z těchto důvodů získávalo urbanistické uspořádání charakter odděleného bloku [...] jedné ulice nebo skupiny domů obklopujících 
jeden nebo více dvorů. Takové sousedství mělo jasně vymezené hranice, své politické centrum, své posvátné hodnoty, svůj výraz i specifický ráz“ (Rossiaud 1997: 136-137). Fasády městských domů tvořily jednotné fronty. Viditelné vymknutí se z této jednoty muselo mít své prííčny nejen praktické, ale i symbolické. Vlastnictví domu ve středověkém městě bylo podmínkou získání společenského i právního statutu v městské obci. Společenské postavení vlastníka domu bylo možné vyjádřit úpravou domovní fasády (malba, plastická výzdoba), výškou domovního štítu, ale také vztahem domu k významným ohniskům města, které představovaly kostely a také budova radnice. $V$ blízkosti těchto ohnisek chtěli mít dům ti, kteří usilovali o větší respekt v městské společnosti. Zaujmutí místa (získání domu) v obraze města bylo tedy i výrazem sociálního zařazení jeho vlastníka do hierarchie městské obce. Kostely tvořily ve struktuře města solitérní jednotky, zatímco radnice byly zařazovány do domovních bloků, byly součástí obce, ale zároveň ji reprezentovaly a byly jejím významovým centrem. Budovy radnic byly zdůrazněny především výškově (měly věže, ale ne tak vysoké jako kostely), někdy byly zdůrazněny i šířkově (zabíraly více domovních parcel) a upoutávaly i výzdobou fasády, ve které se vyskytovala témata a symboly reprezentující městskou obec jako celek a spravedlivou vládu nad městem, která se odkazovala $k$ Bohu. Obdobné náměty a symboly se objevovaly i ve vnitřním vybavení radnic. Vnitřní členění radnic odpovídalo potřebě zasedání sboru konšelů (v Kutné Hoře jich bylo v předhusitské době 12 až 18) v čele s rychtářem a dále i obecních pánů (4), občas ještě se staršími obce (30). Radnice byla místem správy, soudu i provozu městské kanceláře (podrobněji viz Štroblová a Altová 2000: 54-57).

Faktickým i symbolickým vymezením obrazu města byly jeho hradby a brány v nich. Tyto prvky tvořily z města uzavřený celek, vymezovaly vnitřní a vnější prostor. Mohutnost hradeb, výška a počet městských bran jsou dány jednak praktickými zřeteli, ale zároveň slouží i jako výraz prestiže města a jeho společnosti. Výstavba a údržba hradeb byla velmi nákladná, a proto stav a mohutnost opevnění vyjadřovaly i bohatství města. Brány město otevíraly (uzavíraly) ve vztahu k okolí, navazovaly na směry dálkových cest a stávaly se orientačními body uvnitř i vně městského obrazu. „Hradby ovlivňovaly celý městský život a dělily obyvatelstvo měst na čtvrti, jež si rozdělovaly stráž a obranu jejich částí a bran, ohlašovaly stř́ídání dne a noci (brány se za soumraku uzavíraly), posvěcovaly vše, co se nacházelo uvnitř, ale především přetváŕely prostor a dodávaly městské krajině její osobitý charakter“ (Rossiaud 1997: 126-127).

Ve středověku byly vztahy mezi objekty a lidmi bezprostřední, existenční a existenciální potřeby lidí - společnosti - se vrstvily a navzájem podmiňovaly. Středověký urbanistický prostor se označoval jako „prostor bezprostředního kontaktu“. ${ }^{4}$ Práce a život se v obrazu města prolínaly. Ve městě nemohl být nikdy člověk sám za sebe, ale stával se součástí celku, žil ve vztazích, které spoluvytvářel a zároveň se jim podřizoval. Člověk ve společnosti musel komunikovat. Město tvořilo rámec této komunikace. Živá komunikace zaniká spolu se společností, která ji užívala, ale komunikace formou uměleckých děl přetrvává a je možné ji zpětně, s určitými riziky nepochopení či zkreslení, interpretovat.

$\mathrm{Z}$ předhusitské Kutné Hory se $\mathrm{v}$ dnešním obrazu města promítá $\mathrm{v}$ ucelenější formě pouze rozvržení městských kostelů. Jelikož mé vnímání tohoto obrazu vychází z obrazových - hmotných - pramenů, chtěla bych tedy postihnout především dobový význam a smysl tohoto roz-

$4 \quad$ Halík (1996: 15) se odvolává na francouzskou historičku urbanistické kultury Françoise Choay. 
vrhu v rámci městského celku. Vtisknutí pravidelného Božího řádu do plánu faktického města vyjadřovalo ve středověku zároveň představu, že každé pozemské město je odleskem budoucího města nebeského - nebeského Jeruzaléma -, a má tedy i eschatologický význam. Učení o posledních věcech (eschatologie) bylo smyslem většiny uměleckých děl, která se nám z doby středověku zachovala, a města můžeme $\mathrm{z}$ dnešního hlediska také hodnotit mimo jiné jako umělecká díla. Eschatologie (Nový biblický slovník 1996: 221, heslo „Eschatologie“) je vyvrcholením celosvětových dějin spásy, které se odvíjejí jako lineární pohyb od časného k věčnému. Bůh řídí události ke konečnému naplnění záměrů, které se svým stvořením má. Středověké město jako obraz světa je zpř́tomněná - realizovaná - novozákonní eschatologie. $V$ této pravidelnosti (řádu) se mimo jiné stává zobrazením teologické jednoty mezi minulostí, prrítomností a budoucností. Město tedy mělo ve středověkých souvislostech a významech rozvržená ohniska všedního a svátečního ${ }^{5}$ života, která se vázala na představu cesty od časného $\mathrm{k}$ věčnému. Ve středověkém městě se tato koncepce času konkretizovala $\mathrm{v}$ cestě nebo alespoň pohledu od kostela ke kostelu (procesí) a od lidských obydlí a pracovišs' k chrámu. Rituálním opakováním cesty z časnosti $\mathrm{k}$ věčnosti jsou i procesí $\mathrm{z}$ města $\mathrm{k}$ chrámu (mezi městskými chrámy), ale i rituály křtu a pohřbu. Zároveň je každý kostel i cestou ke Kristu a v Kristově osobě a v jeho poslání $(L$ 17, 20) je Boží království prítomné ,již a ještě ne“ (Nový biblický slovník 1996: 221, heslo „Eschatologie“). Architektura chrámu je symbolickou cestou od časného k věčnému. Okna jsou filtrem časného světla od slunce, hvězd a měsíce a mění ho (materií výplně i obrazy v ní zachycenými) ve světlo věčné, Boží. Chrámový portál je výrazným předělem mezi časným a věčným, otevírá cestu (pohled) k oltáři, na kterém se odehrává rituál mše. Vnímání času v kontextu spásy byl (vedle praktických hledisek) často podř́zen i výběr materiálů určených pro stavby a umělecká díla. Zatímco lidská obydlí byla většinou stavěna z pomíjivých materiálů (dřevo, proutí, sláma), kostely se stavěly z kamene. ${ }^{6}$

Vedle člověkem vykonstruované představy lineárního času města samozřejmě podléhala i přírodnímu cyklickému času - stř́́dání noci a dne či ročních dob (Kratochvíl 1996: 80). Města se na rozdíl od venkova postupně více osvobozovala od závislosti na prírodním čase, přesto však pravidelné opakování př́ŕodních cyklů určovalo i rytmus praktického života a bylo zároveň vnímáno jako symbol věčnosti. Př́rodní čas a jeho projev - proměny intenzity přirozeného světla - ovlivňují praktickou i symbolickou orientaci staveb ke zdroji světla a časomíry - slunci (světovým stranám) - a vědomé uspořádání architektonického nebo urbanistického celku, to, jak a kdy má prrijímat (nepřijímat) přirozené světlo. Přirozený čas v podobě světla město obklopuje a vstupuje do jeho vnitřku. Většina obyvatel báňských měst však pracovala ve tmě v podzemí, měla proto jiný vztah k přirozenému času, nerytmizovala svůj život podle střídání světla a tmy, ale podle pracovních směn. Proto se i v Kutné Hoře relativně brzy zavedlo mechanické měření času. Už před rokem 1375 hodiny na radniční věži odbíjely a koordinovaly život ve městě, byly to jedny z nejstarších věžních hodin v Evropě (Leminger 1924: 81-83, Matějková 1962: 18, Burke 1996: 197).

5 Sokol (2004: 36-37, 40-41) navrhuje s odvoláním na Cassirera a Rappaporta užívat místo termínů „profánní a posvátné“ výrazy „všední a svátečni““.

6 Veřejné městské stavby a reprezentativní domy nejbohatších obyvatel města výběrem stavebního materiálu a ikonografií výzdoby také vyjadřovaly ambice trvat pokud možno věčně. 
Hustota sítě městských kostelů, které v Kutné Hoře vznikly v době dlouhého 14. století, svědčí jednak o demografické hustotě města $\mathrm{v}$ dané době, ale také potvrzují i z jiných pramenů vyplývající dojem, že výhody a rizika hornického povolání vedly k obzvláštní zbožnosti, která se mimo jiné projevovala v investicích do výstavby a vybavení kostelů. Povolání, které velkému množství lidí umožnilo dobře žít, vedlo zároveň i k touze „dobře umřŕt“. Představa dobré smrti vycházela v té době již z plně doktrinálně prosazené koncepce očistce. "Zemřít ve smíŕení s Bohem a zachránit se v očistci opravňuje žít plným životem. Přechod do očistce sice vyžaduje peníze, ale zároveň i rozšiření sítě duchovní pomoci, a ,demokratizace mší zpř́stupňuje ,dobrou smrt““ (Rossiaud 1997: 147). Tuto koncepci ve vztahu k obyvatelům hornických osad a později i města jistě prosazovali sedlečtí cisterciáci, protože prostřednictvím malínské fary ovládali všechny hornické kaple a kostely, ze kterých jim plynuly důchody. Potvrzuje to mimo jiné i podíl cisterciáků na výstavbě prvních městských kostelů i snaha udržet si co nejdéle patronátní právo $\mathrm{k}$ nim.

\section{Hora a horníci}

Kutná Hora vznikla na místě nálezu stříbrné rudy. Prospektoři a důlní odborníci, těžařští úředníci a podnikatelé (většinou Němci) přicházeli jednak od Jihlavy ve směru rudních žil, nebo z Prahy, někteří se krátce předtím usadili v Kolíně nebo Čáslavi, ale posléze se usídlili prŕmo na místě těžby a společně usilovali o přerod hornického sídliště v město. Pocházeli z významných patricijských rodů (podrobněji viz Štroblová a Altová 2000: 54-57), které získaly majetek a postavení ve starších báňských a královských městech v Německém Brodě, Jihlavě, Praze, Brně aj. Označovali sami sebe za horníky a byli tak uváděni i dobovými kronikáři (tzv. Dalimil, Petr Žitavský ad.). Jistě se tak vymezovali vǔči velkému počtu nemajetných a jazykově různorodých nově př́chozích, kteří miŕili $\mathrm{k}$ perspektivnímu místu těžby z venkova a měst. Byli to lidé mluvící různými jazyky; sdružovali se na základě místa svého původu; zakládali jednotlivé osady, ve kterých udržovali své původní kulturní zvyky (archeologické nálezy dokládají užití s sebou přinesené keramiky a lokálních výrobních technologií). ${ }^{9}$

Pozemky, na kterých se těžilo, patřily pražské kapitule a z větší části Sedleckému klášteru. Podle práva však náleželo všechno nerostné bohatství v zemi panovníkovi (právo horního regálu). Zpočátku spadala tato nová naleziště právně do jihlavsko-německobrodského ${ }^{10}$ revíru (jihlavské horní právo). Jejich církevní správu zajišt’ovali prostřednictvím fary v Malíně sedlečtí

Kterou už pro přelom 12. a 13. století prokázal ve svých dílech o středověku Jacques Le Goff.

8 Avšak už ve druhé polovině 15. století se označení horník přeneslo i na běžné řemeslníky a obchodníky, kteří zároveň ještě částečně podnikali v dolech a hutích nebo v obchodu s rudou. Od 16 . století dále se označení horník užívalo pro jakéhokoli př́islušníka městského stavu a platilo ve smyslu Kutnohořan, ale bylo spojeno i s nošením hornického kroje a pracovního náčiní při mimořádných prríležitostech (slavnosti, procesí, pohřby). Označení havíŕ, které nyní splývá s termínem horník, se ve středověkých báňských městech užívalo pro pracující v dolech. Za upozornění děkuji archeoložce J. Valentové.

Havlíčkův Brod. 
cisterciáci. Vsi náležející Sedleckému klášteru a pražské kapitule zřejmě také poskytovaly nově př́ichozím nezbytné zemědělské a řemeslné produkty. Pro rychle rostoucí sídliště a rozvíjející se báňský provoz bylo nutné zajistit i široké zemědělské, surovinové a řemeslné zázemí.

Zdá se, že první formou, která konkretizovala shluk hornických osad jako společně sdílené místo, byl jeho název. Od konce sedmdesátých let 13. století se začal v písemných pramenech uvádět ve vztahu k tomuto místu latinský název Mons nebo Montes, německy Berg, česky Hora nebo Hory s prrívlastkem Cutta, Chutta, Cuthna, nebo Berg zu den Kutten (Kuttin Chuttin), Kutné Hory, Hory Kutny (podrobněji tamtéž). Jméno pomyslně vymezovalo místo a zároveň vystihovalo i jeho charakter. Podle př́slušnosti k pojmenovanému místu se identifikovali i lidé, jako např. „Gotfried od Hory““ (v listině z roku 1276).

Původním záměrem panovníka a majitelů pozemků, na kterých se ruda nacházela, zřejmě bylo přenést dozor nad rozrůstající se těžbou na města Čáslav a Kolín, která vznikla krátce po sobě u dálkových cest procházejících touto krajinou ${ }^{11}$ kolem poloviny 13. století. Kolínští a čáslavští patricijové vedli kompetenční spory, které vyústily v roce 1289 do uzavření dohody o vymezení působnosti obou měst nad horským sídlištěm. Hranice působení jim stanovil horský hormistr (těžařský úředník) a jako svědci vystupovali kromě rychtářủ a př́isežných Kolína a Čáslavi také Montani (horníci) (podrobněji tamtéž).Vydavatelem listiny byl úředník působící v Hoře, jako obyvatelé Hory se označili i svědkové, to svědčí o tom, že Hora už měla své reprezentanty a začala se vymezovat i právně. Tato dohoda fungovala v praxi cca. deset let, v té době spravovaly horské sídliště městské rady Kolína a Čáslavi, ale současně se vyvíjela i vnitřní správa Hory, která má městský charakter (rychtář s poradním orgánem, horským soudem; nejstarší známá pečet' rychtáře a přísežných vznikla na přelomu 13. a 14. století, přesný rok jejího vzniku není znám) (podrobněji tamtéž). O roku 1291 je doloženo, že Hora měla i vlastního urburéře (královský úředník, který vedl horní úruad) (podrobněji tamtéž).

Společenské postavení horníků záviselo na jejich odborných i obchodních schopnostech, na osobním úspěchu, bohatství a královské př́zni. Kupovali a pronajímali si od krále významné úrady a zároveň i podnikali v hornictví a usilovali o získání pozemkového vlastnictví v okolí města. Vytvořili úzkou skupinu městského patriciátu. Sami sebe vymezovali označením ,horníci“, které vnímali nejen profesně, ale i stavovsky. Chtěli se jím odlišit od běžných řemeslníků a obchodníků i námezdních pracovníků. Společenské vymezování horníků se rodilo zároveň s úsilím o uznání a uspořádání Hory jako města, a proto se projevovalo i v neobvykle silné identifikaci s místem a s jeho báňským charakterem. Práce spojená s těžbou, zpracováním a obchodem s rudou jim zajistila nejen existenci, ale i společenské postavení, proto jí přikládali i existenciální význam. Sdružovali se podle profesí do korporací a jejich prostřednictvím ovládli i společenský a politický život města. Do určité míry jim tyto pracovní vztahy mohly nahradit rodové (pokrevní) vazby a zakotvit je v rámci feudální společnosti. Jménem místa a své profese vystupovali před panovníkem a dalšími institucemi, usilovali o moc, kterou pak společně reprezentovali. Pracovní nástroje $^{12}$ se staly jejich korporativními znaky a později i součástí znaku města.

11 Starší lidská sídla v této krajině: hradiště Malín (10. stol.)., hrad Č́alav (12. stol.), cisterciácký klášter v Sedlci (od 1142), ves Pněvice náležející pražské kapituli (12. stol.).

Mlátek a kladívko. 
První horníci se sdružovali do společenstev podnikatelů - nákladníků (kverků). Tak se vytvářely specifické ekonomické nájemní a námezdní vztahy, které určovaly i rozvrstvení městské společnosti. Je zřejmé, že odlišná společenská struktura vytvářela i odlišnou kulturu a mentalitu. Horníci se postupně vymykali ze středověkých forem hospodaření, jejich kariéry byly strmé, jak při cestě vzhůru, tak i naopak. Ve feudální společnosti se museli vyrovnávat, stejně jako ostatní měštané, s nevýhodou neurozeného původu, proto věnovali tolik pozornosti osobní a korporativní reprezentaci, pro kterou hledali formy a způsoby, které by je odlišovaly od šlechty. Na rozdíl od profesně různorodě zaměřných měštanů měli výhodu společného profesního zájmu, se kterým spojili i svou kolektivní stavovskou reprezentaci. ${ }^{13}$ Předpokládám, že právě horníci byli tou skupinou, která se ve spolupráci s představiteli Sedleckého kláštera snažila vnést do původně chaoticky rostlého sídliště - města - pravidelný réád daný především rozmístěním městských kostelů, veřejných budov a rozvržením bloků obytných domů ve vztahu k městským uzlům. ${ }^{14} \mathrm{~V}$ tomto procesu cíleného formování města brzy dospěli k záměru, že by jejich pozici posílilo i ustavení vlastní městské církevní správy. Využili původní společnou koncepci umístění a budování kostelů a městského špitálu a hřbitova jako základu k založení městských farních obvodů. Své ambice reprezentovali velikostí a zdobností sakrálních staveb i výběrem reprezentativních architektonických typů. Dostali se do vleklého sporu o patronátní právo s cisterciáky, který se jim podařilo vyhrát těsně před vypuknutím husitských válek. Společenské postavení horníků záviselo také na královské př́zni. Král potřeboval mít kontrolu nad výnosy z kutnohorských dolů a nad provozem mincovny a volil za své úředníky horníky; docházelo také $\mathrm{k}$ tomu, že se př́slušníci dvora ve funkci horních úředníků usídlili v Kutné Hoře a byli přijati mezi horníky. Z tohoto spojení se rodila kultura hornického (horního) města usilující o srovnání s kulturou dvorskou a kultura dvorská, závislá na kutnohorském stř́ibře. $V$ důsledku to znamenalo účast dvorských umělců a nakonec i dvorské stavební hutě na hornických zakázkách, užití ikonografických schémat dvorské kultury a architektonických typů a forem královské reprezentace v kultuře horního města. Účast horníků na královských zakázkách samozřejmě nebyla zviditelňována tak okázale. ${ }^{15}$

Domnívám se, že v předhusitském období rozvoje Kutné Hory nedovolovaly ještě obecně panující středověký kulturní řád ani konkrétní existenční i existenciální závislost města na sedleckých cisterciácích a panovníkovi rozvinutí prvků modernity ${ }^{16} \mathrm{v}$ aktivitách horníků. Takové

13 Která se v 15. století projeví i specifickou „pracovní“ hornickou ikonografií v sakrálním kontextu (nástěnné malby a iluminace).

14 Uzly jsou podle K. Lynche ,strategickými ohnisky, do nichž může pozorovatel vstoupit. Jsou to bud' křižovatky, nebo jiné specifické formy koncentrace s určitou charakteristikou. Ačkoli abstraktně je chápeme $\mathrm{v}$ image města jako body, ve skutečnosti se uzlem mohou stát i velká náměstí a rozsáhlejší lineární útvary“ (2000: 73).

15 Pro předhusitské období tyto vazby předpokládáme, v konkrétních uměleckých dílech je máme nápisy a heraldickými znaky i souvisejícími písemnými prameny potvrzené až pro dobu lucemburskou a jagellonskou.

16 Mám tím na mysli prosazování individuality a s tím souvisejícího sebevědomí městského stavu a jeho úsilí o společenské postavení, které by přssahovalo (rozbíjelo) tradiční strukturu feudální společnosti. 
projevy můžeme sledovat až v průběhu 15. století. Avšak v českém prostředí svým rozsahem a uměleckou náročností ojedinělá stavební aktivita kutnohorských horníků v dlouhém 14. století nasvědčuje, že už v této době vnímali obraz města a především sakrálních staveb jako způsob reprezentace vlastního stavu a místa, se kterým se identifikovali, a to jak v kontextu pozemského bytí, tak i v horizontu dějin spásy. Právě propojení časného s věčným dávalo stř̌edověkým městům jejich ráz a smysl.

I pozdější vývoj ukazuje, že riskantní hornické kariéry vedly na jedné straně k obzvláštní zbožnosti, kterou provázela velká štědrost a vědomí, že investice do výtvarného díla je samozřejmě dar, obět' Bohu, př́ležitost, jak uchovat ,pamět"“ na svou osobu, rodinu, korporaci po dobu čekání na poslední soud. Byl to způsob reprezentace, která měla smysl už v pozemském životě a zároveň i v kontextu dějin spásy. ${ }^{17}$

\section{Proces vzniku městského obrazu Kutné Hory}

Zřejmě v souvislosti se zř́zením úřadu horského urburéře (1291) mohlo být v závěru 13. století rozhodnuto o výstavbě hradu v blízkosti křížení dálkových cest od Kolína, Sedlce a Čáslavi, na ostrohu nad řičkou Vrchlicí a cestou od Kouřimi (doba vzniku není doložena písemnými prameny, ale analýzou vejčitého půdorysu; Muk a Lancinger 1985), který měl sloužit jako sídlo horního úřadu a sklad vytěžené rudy (předtím se každodenně vozila do Prahy). Jeho stavba tedy byla především v zájmu panovníka, ale i horníků. Je možné předpokládat, že král byl stavebník a horníci investoři, hrad měl tedy zároveň královský i městský charakter. Krátce po roce 1300 byl přestavěn ještě pro potřeby provozu centrální mincovny (podle florentských specialistů, kteří byli v té době přizváni $\mathrm{k}$ zavedení ražby pražských grošů, se pro něj od poloviny 14. století rozšířilo označení „Vlašský dvi̊r“). Tehdy ještě nebylo město spolehlivě opevněno, šlo tedy o jediné bezpečné místo větší rozlohy. V př́zemí hradu po vnitřním obvodu nádvoří vznikly paprsčitě uspořádané jednotlivé mincovní provozy, které měly vstupy z nádvoří. Na nádvoří se také pracovalo a zároveň do něj vjížďly vozy s rudou a dalším potřebným materiálem, bylo proto nutné zř́dit další vjezd, aby se nemusely otáčet. $V$ patře byly kanceláře a horní archiv. Zda v tomto období byla zř́izena i panovnická rezidence, není zřejmé. Uspořádání prostorů hradu bylo dáno především praktickými zřeteli souvisejícími s provozem mincovny.

V blízkosti Vlašského dvora vznikaly samostatně opevněné obytné celky, které sloužily jako sídla prvních horníků v době, kdy ještě Hora neměla vlastní opevnění. Byly to různě koncipované solitérní objekty (podrobněji viz Altová a Pospíšil 2000: 229). Nejstarším z nich byl patrně věžový dům na místě pozdějšího Sankturinovského domu čp. 377 na Palackého náměstí, který stál u křižovatky dálkových cest ve středu pozdějš́ího města, v suterénu jeho obytné věže byl v průběhu šedesátých let 20 . století objeven zbytek tavicí pece z poloviny 13. století a systém horkovzdušných kanálků v podlaze a ve zdivu věže vedoucí až do výše prvního podlaží, kterými se odvádělo zbytkové teplo od pece, aby vytápělo její obytná patra (Matějková 1969). Jde o zajímavý př́pad promyšleného spojení výrobní a obytné funkce

17 Druhý extrém hornické mentality už není dnes tak viditelný, ale odrazil se nepřímo v písemných pramenech a v později zaznamenané orální historii. Byl to sklon k užívání si života, který se projevoval v zálibě v přepychu, v pořádání slavností a bujarých zábav. 


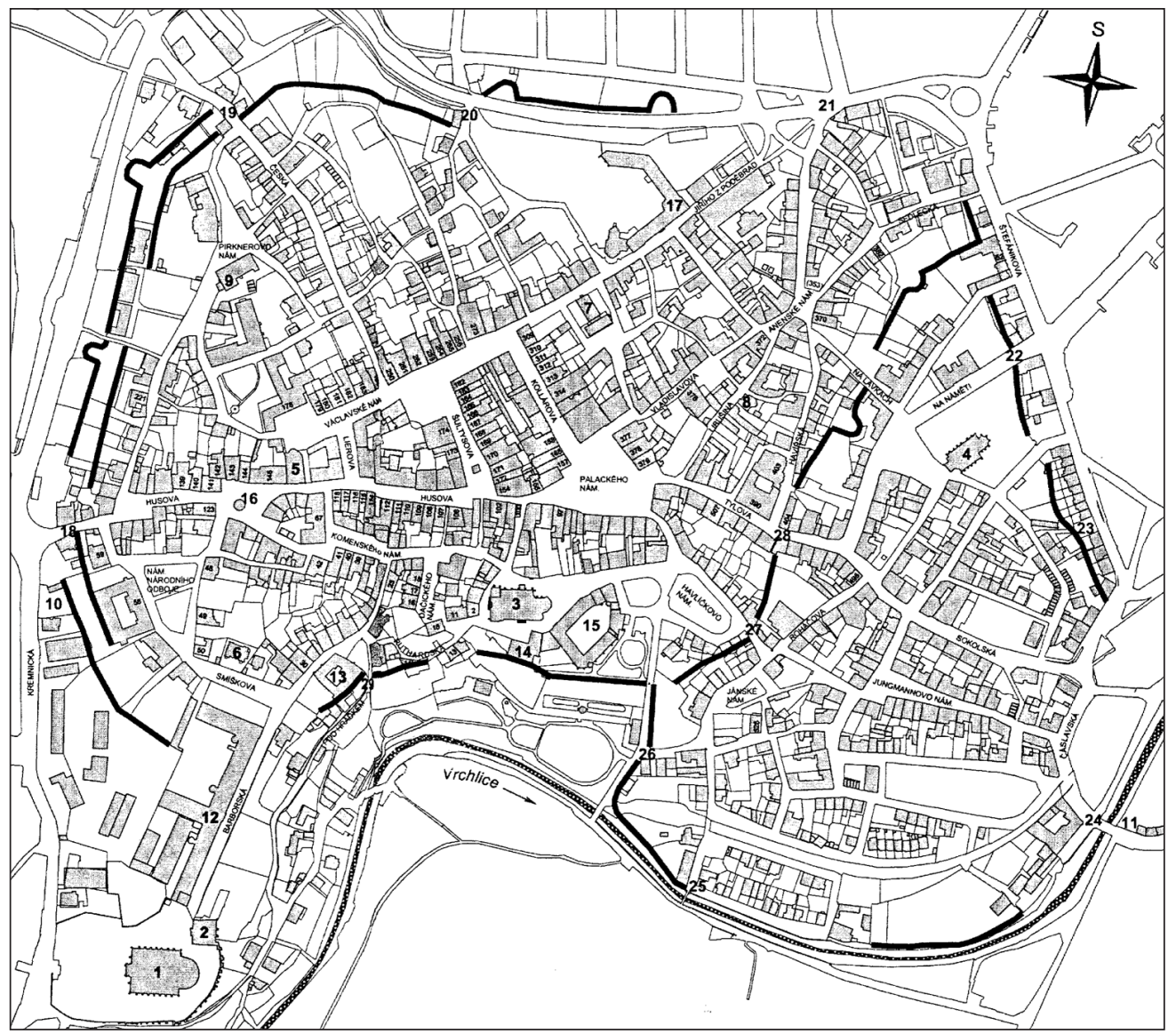

Obr. 2: Plán historického jádra Kutné Hory (A. Pospišil ve spolupráci se Š. Kavkou) Autorka děkuje kolegům za souhlas k publikování plánu.

\section{Kostely a kaple:}

1. Chrám sv. Barbory

2. Kaple Božího těla

3. Kostel sv. Jakuba (horní kostel Panny Marie)

4. Kostel Panny Marie $\mathrm{Na}$ Náměti (dolní kostel Panny Marie)

5. Kostel sv. Jana Nepomuckého

6. Modlitebna Církve československé husitské

7. Modlitebna Českobratrské církve evangelické
8. Bývalá kaple nejsv. Trojice

9. Bývalý kostel sv. Bartoloměje

10. Zaniklý kostel sv. Jiří

11. Zaniklý kostel sv. Kříže

\section{Monumentální stavby:}

12. Jezuitská kolej

13. Hrádek

14. Arciděkanství

15. Vlašský dvůr

16. Kamenná kašna

17. Voršilský klášter
Zaniklé brány:

18. Kouřimská brána

19. Kolínská brána

20. Hloušecká brána

21. Klášterská brána

22. Nová brána

23. Katova branka

24. Čáslavská brána

25. Novomlýnská branka

26. Žižkova brána

27. Leflirsská branka

28. Stará brána

29. Podhrádecká branka 
v jednom objektu. Samostatně opevněné věžové domy vznikaly v té době i v jiných městech, např́íklad i v Praze na Havelském městě. Spojení fortifikační i obytné funkce se předpokládá i u dalších tzv. věžových domů, které vznikaly v blízkosti Vlašského dvora. Jeden z nich patřil rodině Ruthardů, ${ }^{18}$ která náležela k první generaci horníků. Solitérním a mimořádným objektem mohl být na počátku 14 . století i Hrádek. ${ }^{19}$ Jeho původní podoba však není známa, je možné, že už v té době mohl mít věž s hrázděnou nástavbou. Byl opakovaně přestavován a v průběhu 14. a 16. století byl vždy mimořádným patricijským sídlem, často v držení královských úředníků. Dalším typem samostatných a opevněných celků, které zabíraly několik pozdějších domovních parcel, byly patricijské dvorce. Zbytky jednoho z nich ${ }^{20}$ který patřil staré rodině Puschů, v Kutné Hoře doložené k roku 1330, jsou dodnes doložitelné v objektech v blízkosti Vlašského dvora. Zdá se tedy, že v prvním období výstavby města si sídla významných horníků uchovala solitérní ráz a nesplynula s ostatní obytnou zástavbou do podoby domovních bloků.

Pravděpodobně v posledním desetiletí 13. století se horníci také mohli dohodnout s panovníkem na potvrzení Hory jako dalšího královského báňského centra s městským charakterem $\mathrm{v}$ této oblasti, zrejejě proto, aby se vymanili z vlivu patriciátu kolínského a čáslavského a posílili svůj vlastní vztah ke králi a k místu těžby. Je možné předpokládat, že to bylo úsilí skupiny horníků, kteří v Hoře zahajovali své kariéry, byli spojeni generačně a svými zájmy. V této době a situaci mohl koncept generace trvat cca třicet let od nástupu kariéry do odchodu do ústraní. Postavení této generace zajisté posílilo vydání horního zákoníku králem Václavem II. v roce 1300, kterým byla Hora nepř́mo potvrzena jako královské báňské město. Na formování města jako bezpečného celku i na soudržnost prvních horníků měly zajisté vliv události let 1304 až 1307, kdy Horu opakovaně neúspěšně obléhal říšskoněmecký císař Albrecht Habsburský. Výrazem dobového postavení horníků v království je i jejich spoluúčast na rozhodování, kdo dosedne na český trůn po smrti Václava III. v roce 1306. Prosazování jednotlivých kandidátů bylo zároveň i bojem o vliv ve městě (Štroblová a Altová 2000: 47-48).

Obléhání Hory Albrechtem Habsburským horníky donutilo opevnit místo nejdříve provizorně, ale před rokem 1307 již stabilními kamennými hradbami s branami na cestách ke Kouřimi, Kolínu, Sedlci a Čáslavi. Do linie opevnění byl začleněn i Vlašský dvưr. Hradby a brány představovaly již faktické i symbolické vyjádření skutečnosti, že Hora je městem.

$\mathrm{Z}$ právního i stavebního vývoje vyplývá, že jádro města se $\mathrm{v}$ té době tvořilo $\mathrm{v}$ prostoru mezi sídlem urburéře a křižovatkou dálkových cest (v místě dnešního Palackého náměstí). Na počátku 14. století ustupovala těžba ze středu Hory a vznikl tedy prostor pro rozvinutí pravidelného a promyšleného plánu, který by vtiskl místu pravidelný rád připomínající rímskou urbanistickou tradici (viz Plzeň, Budějovice, Klatovy). Složitý terén s pozůstatky po důlní činnosti (haldami) a některými ještě funkčními důlními provozy, excentricky umístěnými

18 Věž zachycena ještě na Willenbergově vedutě Kutné Hory z roku 1602, pod číslem 21. Dům stál v dnešní Ruthardově ul., na místě čp. 14.

19 Objekt od 1312 až 1314 označený jako castrum - hrádek (Hermanus de Castro) v průběhu 15. století „duom Hrádek řečený" . 
staršími a nadále potřebnými objekty, nedovolovaly jeho ideální rozvinutí v centralizované ortogonální prostorové osnově. Plán byl vymezen hradbami, které vznikly před rokem 1307, a cestami od Kouřimi, Prahy, Kolína, Sedlce a Malína. Podél těchto cest byly založeny pravidelné městské bloky, které původně na určitých místech často tvořily tzv. pilovitou uliční frontu (Vinař 2004), kdy domy postupně vystupovaly z uliční fronty, aby bylo vidět hlouběji do ulice nejen z hlavního průčelí, ale i z boku domu. Předpokládá se, že v té době byl zastavěn celý stř̌ed města. $Z$ tehdejších objektů jsou zachovány pouze sklepy. Byly obvykle dvoupatrové, výjimečně třípatrové, překryté rovnými stropy z kamenných desek na dřevěných trámových konstrukcích. ${ }^{21}$ Zaujímaly větší rozlohu než pozdější domy nad nimi, byly mezi sebou propojené půlkruhovými kamennými portály, a to jak v uličním bloku, tak i přes ulici. Vstupovalo se z nich i do důlních děl. Provázání obydlí s místem práce mohla trvat pouze do vyčerpání zásob rudy v prostoru městského jádra. Rodinný život a pracovní místo se postupně oddělovaly. Domovní bloky byly do hloubky přerušovány úzkými uličkami, které sloužily jako stoky a označovaly se v Hoře i v jiných středověkých městech pro svůj zápach ironicky jako „růžové“ nebo „královské“ (Vinař 2004). Členitý a svažitý terén města, nedostatek pitné vody, provázanost zástavby a důlních děl, mimořádné nároky a možnosti stavebníků, jejich různorodé podnikání a časté požáry vytváŕely nestandardní podmínky a zadání pro výstavbu domů. Není možné tedy v počátečním období rozkvětu města postihnout jen jeden typ domu, ${ }^{22}$ ale hned jejich celou škálu a často i zcela ojedinělá uspořádání (Altová a Pospíšil 2000: 327). Avšak je obtižné alespoň jeden $\mathrm{z}$ nich popsat $\mathrm{v}$ takové celistvosti, aby bylo možné si představit, jak se v něm žilo. ${ }^{23}$ Profese majitele zřejmě určovala, zda ji mohl vykonávat doma, a tedy zda potřeboval výrobní a skladové prostory, nebo zda za prací docházel do podzemního či povrchového provozu. Předpokládáme, že když byly domy tak často předmětem obchodu, existoval univerzálnějš́i typ, který vyhovoval majitelům různých profesí, jak to pak můžeme podrobněji sledovat ve století 15 . a 16 . Charaktery předhusitských domů zanikly pod pozdějšími přestavbami. $Z$ dobového pojetí a rozsahu rodiny však vyplývá, že v domě společně žila nejbližší rodina majitele (manželský pár, děti) se staršími, již profesně neaktivními, ovdovělými a neprovdanými př́buznými manželů, dále i služebnictvo a př́padní zaměstnanci. „Městské obyvatelstvo se v největší míře skládá z malých domácností, z rodin čítajících velmi málo osob. Městská rodina je mnohem menší než venkovská,“ uvádí Rossiaud (1997: 130). Ale i tak vedle sebe v těsné blízkosti žilo společenství nejrůznějších lidí, kteří společně užívali kuchyň i obytné prostory. Část pracovních i společenských aktivit rodiny se odehrávala na ulici (náměstí) před domem, kde se rodina potkávala se sousedy. Život ve městě znamenal neustálý kontakt s množstvím lidí.

V tomto prvním urbanistickém konceptu Kutné Hory se patrně počítalo i ze založením dvou pravidelných náměstí (Vinař 2004). Jedno mělo být mezi dnešní Kollárovou a Šultysovou ulicí, ale pro nedostatek místa bylo ještě před husitskými válkami zastavěno budovou radnice (její podoba není známa) a frontou masných krámů. Druhé náměstí mělo být v prostoru nyněj-

$21 \quad$ Klenuly se až později.

22 Není možné ani doložit užití jinak běžného průjezdového domu v předhusitském období.

23 Takové možnosti nabízí až průzkum městských domů z 15. a 16. století. 
šího Palackého náměstí, na hlavní cestě městem od Klášterské brány ke Kouřimské (bylo zastavěno na konci 15 . století budovou nové radnice s průjezdním dvorem). Funkci veřejných prostranství zastávala místa trhů. ${ }^{24}$

Město se v úrovni dnešního Jánského náměstí, Roháčovy a Sedlecké ulice hradbami dělilo na horní a dolní, podle toku řeky. Horní město bylo začleněno do linie nejstarších hradeb před rokem 1307, dolní pravděpodobně až v polovině 14. století. V horním městě se soustředily významné veřejné světské i sakrální budovy, domy horníků a trhová místa (v centru masné krámy, rybí trh, trh s obilím, zeleninou apod., ale i tzv. bleší a hrnčířský, na okraji trh koňský a se dřevem). V dolním městě se nacházely méně významné kostely a domy měšt’anů, tedy běžných řemeslníků a obchodníků. Na jeho okraji byly hospodářské budovy a rudný trh.

Cesta od hornických sídlišt' k městskému celku představuje proces hledání a vytváření společně sdíleného řádu zviditelněného $\mathrm{v}$ architektuře a urbanismu, proto může být i vyjádřením společenských představ a vztahů. Kutná Hora byla ve starší odborné literatuře prezentována jako město vznikající bez promyšlené urbanistické koncepce. Až v průběhu druhé poloviny 20. století byl v jejím uspořádání postupně odhalován pravidelný řád. ${ }^{25}$ Proces proměny chaoticky rostlého sídliště v systematicky koncipované město vyplývá z přirozených potřeb středověké společnosti dát místu pobytu vyšší řád a projevuje se ve větší či menší míře u všech středověkých sídel. Bylo třeba vytvořit bezpečné místo, to neznamená místo pouze ohradit, ale především ho uspořádat tak, aby bylo možné se v něm prakticky orientovat. Městský prostor byl pro středověkého člověka relativně novou zkušeností, byl těžko uchopitelný a zbavený zřetelné perspektivy, kterou člověk znal z venkovské krajiny. I ve městě se člověk potřeboval orientovat, tedy vztahovat ke slunci, světu, a tedy k vesmíru, a to už byl zároveň symbolický vztah. Město bylo nejen místem práce, ale i odpočinku. Právě ve společném sdílení, v hledání pocitu bezpečí, který se posiluje orientací v prostoru a v rytmu života, se existenční potřeby plynule přesunuly do sféry existenciální. Společné místo a společný program tvořily společnost a ta hledala smysl své kolektivní existence, který ti, co chtěli mít vliv (moc), vizualizovali v obrazu města.

\section{Městské kostely jako obraz společnosti}

Předpokládá se tedy, že už vedle provizorních př́bytků rozmístěných v hornických osadách vznikaly kaple nebo že se založení těchto osad mohlo nějakým, v té době obvyklým, způsobem vztahovat ke starším kostelům, které byly v dané oblasti již dříve ve vsích náležejícím Sedleckému klášteru nebo pražské kapitule. Kritérii mohlo být např́iklad to, aby byly dosažitelné v přijatelné době pěšky nebo na voze (například v případě pohřbu), byly v doslechu zvonů nebo na místě, odkud se dalo dohlédnout k věžím. Patronátní právo k hornickým kaplím uplatňovali sedlečtí cisterciáci, kteří ale podle svých regulí nesměli vykonávat pastorační činnost. Prosazení patronátního práva k hornickým svatyním bylo však pro ně jedinou možností, jak se podílet na bohatství pocházejícím z nalezišt’ rudy na jejich pozemcích, proto je vykonávali pro-

24 Jejich rozmístění se zachovalo v místních názvech až do 19. století.

25 Zásadní práce pojednávající o urbanistickém vývoji Kutné Hory: Leminger (1927), Herout (1949), Handiaková (1958), Kruml (1991), Vinař (2004). 
střednictvím malínské fary, kam dosazovali své faráře. Pobírali důchody za pravidelné liturgické služby, odkazy k jednotlivým oltářům, poplatky za křty, pohřby i dotace na provoz klášterního špitálu, který sloužil i obyvatelům Hory. Původní rozloha malínského a sedleckého hřbitova dokládá, jek velká a lidnatá, a tedy i výnosná to byla farnost. (Ve Zbraslavské kronice je uvedeno, jak v jediném roce bylo pohřbeno na sedleckém hřbitově 30000 lidí.).

V Kutné Hoře se začalo s výstavbou reprezentativních městských kostelů poměrně pozdě (ve srovnání s vývojem městského práva, správy apod.), ale zato ve velkém počtu a v monumentální podobě. Nad starými hornickými kaplemi i nad nově odhalenými posvátnými místy vznikaly $\mathrm{v}$ průběhu 14 . století $\mathrm{v}$ rychlém sledu stavby, které měly vyjadřovat ambice městské společnosti jako celku nebo ambice profesních a náboženských korporací, které se s městem identifikovaly. Městské kostely obvykle tvořily centra jednotlivých farností, ale v předhusitské Kutné Hoře byly všechny kostely filiální a vztahovaly se k malínské faře. Přesto představovaly pro každou část města společné kultovní místo a posilovaly sousedské a s nimi i profesní vztahy, protože jejich stavebníky byly profesní korporace. Tento projev byl v Kutné Hoře zpočátku ovlivněn a usměrňován Sedleckým klášterem. Město začalo budovat své první kostely ve dvacátých letech 14. století ve spolupráci se sedleckou stavební hutí a podle klášterních vzorů, ale také zároveň s ambicí vytvořit si vlastní církevní správu a vymanit se z vlivu kláštera. To už byl program druhé generace horníků, která nastoupila v této době stabilizace Kutné Hory jako města a vytkla si za svůj cíl jeho okázalou reprezentaci. Zřízení vlastní městské církevní správy bylo otázkou prestiže, ale mělo i význam praktický a ekonomický. Všechny tyto okolnosti se projevily při výstavbě městského špitálu na předměstí zvaném Kolmark (Karlov) za Čáslavskou branou. Stavebníkem špitálu byl kutnohorský patricij Štěpán Pirkner, který svou investici zakládal na tom, že špitál se bude provozovat $\mathrm{z}$ důchodů z městských kaplí, které doposud pobírali cisterciáci, a posléze i z odkazů měštanů a že on i jeho dědicové z nich získají podíl. Malínský farář však prosadil k novému špitálu svůj nárok, i když ten si zachoval charakter městské instituce, a Pirkner se musel o výnosy s malínskou farou dělit.

Ve třicátých letech 14. století se malínská fara stala obročím vyšehradského probošta a českého kancléře Jana Volka. Ten byl v roce 1332 jmenován olomouckým biskupem, ale důchody z malínské fary si ponechal a sedlečtí cisterciáci je nemohli využívat. Na přelomu dvacátých a třicátých let 14. stoletíi ${ }^{26}$ začali horníci stavět v blízkosti Vlašského dvora ${ }^{27}$ ve středu horního města, kde už v té době byla poměrně hustá obytná zástavba, první kamenný městský kostel. Stavěla jej sedlecká stavební hut' a byl zasvěcen Panně Marii, ${ }^{28}$ stejně jako konventní kostel v Sedlci, a byl také orientován $\mathrm{v}$ ose sedleckého kostela po proudu řeky, jak bylo cisterciáckým zvykem. Téměř současně s ním začala stavět sedlecká hut' obdobný typ kostela na dolním městě; i tento kostel byl zasvěcen Panně Marii a orientován po proudu řeky. Přenesení mariánského zasvěcení i specifické cisterciácké orientace a technologie výstavby sakrálních staveb na

\footnotetext{
26 První písemná zmínka z roku 1336.

27 Vztah kostela $\mathrm{k}$ Vlašskému dvoru byl zřejmě významově důležitější než praktická úvaha nad výběrem místa. Terén nad údolní hranou byl pro stavbu kostela nevhodný a navíc už z větší části zastavěný, takže neposkytoval možnost pro rozvinutí stavby a založení hřbitova nebo náměstí.
}

Současné zasvěcení sv. Jakubu Většímu se užívá od konce 15. století. 


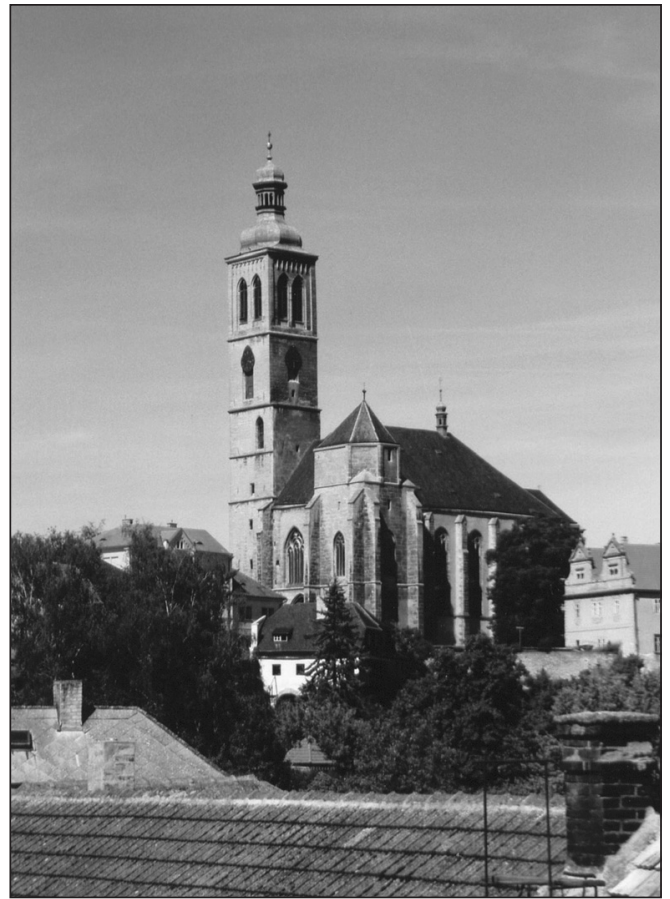

Obr. 3: Kostel sv. Jakuba v Kutné Hoře, pưvodně horní kostel Panny Marie. Zdroj: archiv autorky. tyto dva městské kostely mělo zajisté potvrdit nárok cisterciáků na patronátní právo k městským svatyním. Stavebníky kostelů však byli horníci, u horního kostela to byl konkrétně cech mincírư a pregéřư ${ }^{29} \mathrm{z}$ Vlašského dvora. Tak jako horníci sdružovali prostředky ke společnému podnikání v těžařstvech, sdružovali je i ke společné reprezentaci profesních skupin a náboženských bratrstev. Vystupovali jako kolektiv osob se stejnými právy a hledali i vhodné způsoby, jak tuto rovnost prezentovat. Vztahovali se k místu svého kariérního uplatnění - k městu, které vnímali i jako místo své osobní a rodové reprezentace. Stavby městských kostelů byly výsostnými obrazy představ o podobě a fungování společnosti středověkého města. Profesní nebo náboženské korporace vystupovaly jako stavebníci celku a hlavního oltáře. Jednotlivé kaple a vedlejší oltáře si kupovaly patricijské rodiny, hradily jejich výstavbu, výzdobu a provoz, určovaly jejich ikonografii a dále s nimi zacházely jako s rodinným majetkem, odkazovaly je v závětích nebo je prodávaly podle potřeby. Bylo v zájmu hlavních stavebníků, aby bylo v kostele možné založit velký počet kaplí a oltár̆ù. Přesto byl kostel vnímán jako obraz celé obce. Postavení laiků k církvi vyjadřuje vztah lodí k presbyteriu, poměr velikosti lodí a presbyteria, poměr výšky klenby presbyteria a lodi, to, kolik stupňů dělí presbyterium od podlahy lodi, zda je dělí příčná lod', přepážka či nikoli a jak je zvýrazněn (potlačen) předěl mezi lodí a presbyteriem, tedy triumfální oblouk. Uspořádání prostoru lodi (lodí) zobrazuje představu o obci a její hierarchizaci, význam obce může vyjádřit i počet a výška věží, ale i monumentalita celé stavby či její struktura a použitý materiál, jeho opracování a uspořádání a zejména vstupní portál.

První městské mariánské kostely byly stavěny za účasti sedlecké stavební huti, ale jistě podle přání horníků. Zatímco sedlecký konventní kostel ${ }^{30}$ je bazilikou katedrálního typu (hlavní lod' je vyšší než lodi boční a kolem chóru probíhá ochoz s věncem ${ }^{31}$ kaplí), horní a dolní mariánský kostel

29 Pregéŕi, prenéři = zaměstnanci mincovny.

30 Sedlecký konventní kostel je od Bayerovy a Santiniho přestavby na přelomu 17. a 18. století pětilodní, ale jižní boční lod' sloužila od jeho založení jako jedno rameno ochozu rajského dvora, byl tedy původně asymetrický, čtyřlodní.

31 Kaple paprsčitě uspořádané kolem katedrálního chóru jsou přístupné z ochozu a tvoří útvar označovaný jako věnec. 
jsou stavby halové (všechny lodě jsou zaklenuté ve stejné výšce). Bazilikální stavba se vyznačuje převýšenou hlavní lodí, do které proudí více světla z velkých oken v převýšené bazilikální stěně, zatímco prostor bočních lodí je slaběji osvětlený menšími a nízko posazenými okny. Konventní kostel kláštera nebyl př́stupný laikům a ve svém hierarchickém uspořádání podle stupně zasvěcení rozlišoval i př́slušníky řádu. Řádová komunita shromážděná v bazilikálním kostele je světlem diferencovaná, takže ti, co jsou vpředu a ve střední lodi, jsou světlem obdařeni více než ti, kteří jsou v šeru bočních lodí a dále od chóru. Chór je od lodí i ochozu oddělen v ráádovém kostele přepážkou a výrazným triumfálním obloukem, dokonce i př́ǐnou lodí.

Stavebníky městských kostelů byli horníci, kteří chtěli vystupovat jako obec mezi sebou rovná nejen v podnikatelské praxi, ale i v kontextu dějin spásy. V halovém kostele jsou všechny lodě zaklenuty ve stejné výšce, poslední klenební pole je zkráceno tak, že trojlodí tvoří takřka centrální prostor a tudíž je celá obec rovnoměrně obdařena světlem. Presbyterium městského kostela vyhrazené kněžím je oproti halovému prostoru obce výrazně menší, zabírá šiř́ku střední lodi, má dvě pole a pětiboký závěr, od lodě je dělí čtyři stupně, ale je zaklenuto ve stejné výšce jako prostor halového trojlodí. Presbyterium není od haly odděleno přepážkou a triumfální oblouk je nevýrazný. Horní mariánský kostel měl mít podle původního záměru dvouvěžové průčelí, ale nejspíše ze statických důvodů nebyla jižní věž dokončena; severní věž ovšem tvoří značně převýšenou dominantu města $(86 \mathrm{~m})$. Do poloviny 14 . století byl horní kostel dostavěn v celém půdorysném obvodu do výše záklenků portálů. Západní portál byl postaven v duchu tradice klasické katedrální gotiky a neměl v té době v Čechách obdobu, je pilířem rozdělen na dva vstupy a má bohatě zdobený kružbový tympanon. Nad posledními západními poli trojlodí se počítalo se založením tribun a pravděpodobně se předpokládalo, že kostel bude propojen s naproti stojícími patricijskými domy, jak to bylo obvyklé u šlechtických sídel. V roce 1800 popsal milčický rychtář František Vavák (Vavák 1918) dojmy z návštěvy Kutné Hory. Na místě dnešních domů čp. 2 a čp. 11 na Dačického náměstí viděl stát dům, který mu připadal ,jako nějaká tvrz ležící proti hlavním dveřím kostela" a viděl jak na domě, tak na kostele stopy po tom, že ,z domu někdy pavlač a chodba a dvíŕka do kostela na kruchtu bývala““.32 Je však možné se domnívat, že obdobné spojení mohl mít od závěru 14. století, kdy se pokračovalo ve výstavbě kostela na úrovni západních tribun, i dům, který na tomto místě stál v této době. Kostel vznikal v již hustě zastavěné části města. Provázanost domovního bloku proti západnímu průčelí kostela se projevila i v sousedním objektu, který stál na místě dnešního čp. 16 (původně zde byl samostatně opevněný dvorec patricijské rodiny Puschů doložený k roku 1330). V závěru 14. století, zréejmě v souvislosti s dostavbou kostela panovnickou hutí, byl v prvním patře tohoto domu postaven kamenný dveřní portál s bohatou kamenickou výzdobou, který má všechny znaky katedrální gotiky a je v rámci měšt’anské architektury té doby naprosto ojedinělý.

Současně stavěný dolní mariánský kostel později několikrát vyhořel a byl přestavován, takže představa o jeho původní podobě je komplikovanější. I zde však měl být užit halový typ kostela s obdobně řešeným vztahem presbyteria a trojlodí. V průčelí však vznikla pouze jedna věž v jeho ose, kterou se procházelo dovnitř. I tento kostel měl jinak v Čechách ojedinělý katedrální portál. ${ }^{33}$

32 Vavák se domníval, že to je dům rodiny Ruthardů, ale byl to pozdně gotický dům kutnohorského šepmistra a „kroječe suken“ Bartoše z Práchňan.

33 Zachoval se až do osmdesátých let 19. století a je zaznamenán v kresbě J. Zacha (1882). 


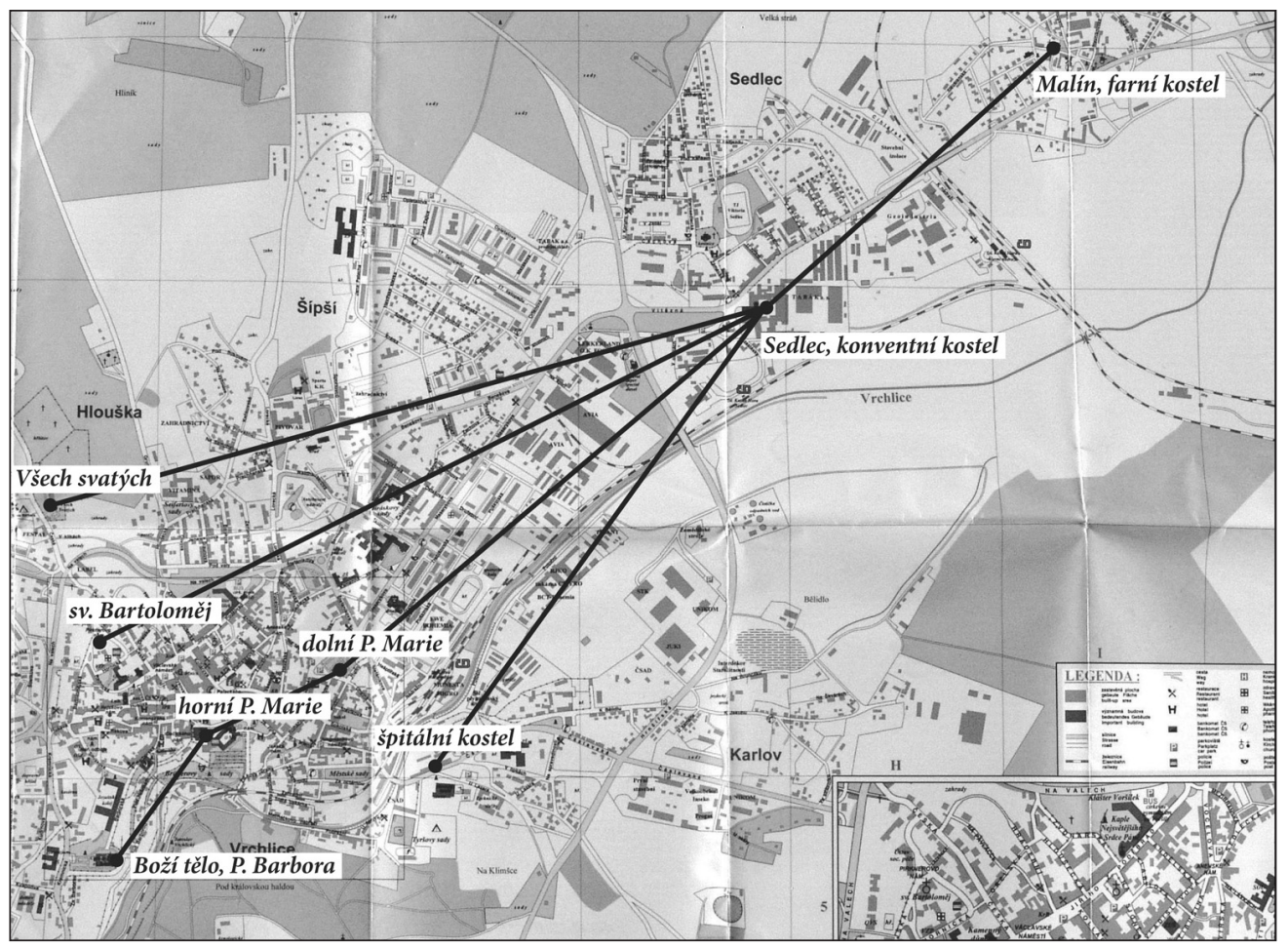

Obr. 4: Současný plán Kutné Hory s vyznačením vztahu městských kostelů k farnímu kostelu sv. Štěpána v Malíně a cisterciáckému konventnímu kostelu Nanebevzetí Panny Marie v Sedlci. Zdroj: autorka.

Do jaké míry mohly být tyto mariánské kostely výrazem snahy horníkủ o vlastní církevní správu není podle jejich architektury snadné určit. I když jejich podoba odpovídá spíše potřebám i představám vlivné městské vrstvy, jejich vztah k malínské faře (tj. Sedleckému klášteru) je zřejmý. Cisterciáci patrně už před zahájením výstavby připravili plán rozvržení svatyn̆ ve městě. Při zkoumání městského plánu ${ }^{34}$ se ukazuje, že tyto stavby byly projektovány na pomyslných přimých vzdušných osách vycházejících paprskovitě od presbyteria malínského farního kostela sv. Štěpána směrem k městu. Na realizaci plánu se však museli podílet i představitelé města a korporací, kteří byli objednavateli staveb a zrejejmě si i prosazovali volbu stavebního typu. Hlavní linie výstavby horských kostelů směřovala od malínského kostela k sedleckému konventnímu kostelu a dále pak k dolnímu a hornímu mariánskému kostelu a byla dovršena v osmdesátých letech 14. století zahájením stavby chrámu Božího těla a sv. Barbory. Mezi městskými mariánskými kostely a kostelem Božího těla a sv. Barbory se v této linii opakuje interval, který má podle současného měření délku cca $420 \mathrm{~m} \cdot{ }^{35}$ Tato vzdálenost se mezi malínským a sedleckým kostelem opakuje třikrát, mezi sedleckým a dolním marián-

34 Na rozdíl od Krumla (1991) a Vinaře (2004) se nedomnívám, že do tohoto plánu měly být také zařazeny světské budovy.

35 Jako první na tento modul upozornil Kruml (1991). 
ským čtyřikrát. Celkem se tedy v pomyslné ose mezi nejvzdálenějším městským a malínským kostelem projevuje tento modul devětkrát. Z malínského farního kostela se tento modul promítne do města ještě $\mathrm{v}$ dalších pomyslných osách ke kostelu sv. Bartoloměje, ${ }^{36}$ který stál za Kolínskou branou, sedmkrát a sedm modulů dělí od Malína i kostel Všech svatých, ${ }^{37}$ který byl patrně centrem hornické osady Stará Kutna a byl tedy starší než městské kostely a později nebyl zařazen do prstence pozdějšího opevnění. Od Malína se vzdálenost $420 \mathrm{~m}$ opakuje šestkrát směrem $\mathrm{k}$ místu, kde byly kostely prvního městského špitálu. ${ }^{38} \mathrm{~V}$ městském plánu je patrná snaha pokud možno opakovat tento modul i ve vzájemných vzdálenostech mezi kostely např́č os od Malína. Jedenkrát se modul promítne do vzdálenosti mezi kostelem Všech svatých a sv. Bartolomějem a opět jeden modul dělí kostel sv. Bartoloměje od horního kostela Panny Marie.

O vazbě městských kostelů $\mathrm{k}$ Sedleckému klášteru vypovídá $\mathrm{i}$ jejich orientace. Malínský kostel, ${ }^{39}$ postavený ještě před příchodem cisterciáků, je orientován na východ, ale cisterciácký konventní kostel je v souladu s řádovými zvyklostmi orientován po proudu řeky a shodou okolností také $\mathrm{k}$ východu, dolní mariánský kostel je orientovaný po proudu na severovýchod, horní mariánský po proudu a shodou okolností k východu, kostel Božího těla je orientován $\mathrm{k}$ východu a kolmo k říčnímu proudu. Vznikl jako nesporný výraz touhy horníků vymanit se z vlivu Sedleckého kláštera (a jeho patronátní správy), byl postaven na pozemcích pražské kapituly, které náležela ves Pněvice ${ }^{40} \mathrm{~s}$ farním kostelem sv. Václava na protějším břehu Vrchlice. Je tedy orientován na východ a ve vztahu $\mathrm{k}$ pněvickému kostelu. Kostel Všech svatých je orientován $\mathrm{k}$ východu a zároveň po proudu, sv. Bartoloměj také tak.

36 Jak vypadal původně, nevíme, na přelomu 14. a 15. století to byl kamenný dvoulodní kostel, z něhož se dodnes zachovala pouze věž. Byl v roce 1783 zrušen a před rokem 1837 zásadně přestavěn pro potřeby nového městského špitálu. Z plánu města $\mathrm{z}$ roku 1813 je zřejmé, že byl orientován v souladu s tokem řeky.

37 Předpokládá se, že vznikl už ve 12. až 13. století, ve starší literatuře je omylem spojován s datem 1292, zapsaným v Pábíčkových pamětech města Kolína (kolínští horníci z vděčnosti za bohatý nález stříbrné rudy postavili kostel Všech svatých). Tento zápis se však vztahuje s největší pravděpodobností ke kostelu téhož zasvěcení, který vznikl v Kolíně v místě bývalé osady Hroby na pravém břehu Labe. Kostel Všech svatých v Kutné Hoře je patrně spojen s nejmladším obdobím osady Stará Kutna. Nepřímo to dokládají zasypaná důlní díla v jeho těsné blízkosti.

38 Za Čáslavskou branou byl postaven ve dvacátých letech 14. století první vlastní městský špitál s kostelem sv. Lazara. V osmdesátých letech zde panovnická hut' postavila jednolodní kostel sv. Kř́že. Byl zbořen v padesátých letech 19. století, ale jeho pozůstatky se dochovaly jako ohradní zdi bývalého cukrovaru v Čáslavské ulici čp. 1-3.

39 Kostel sv. Štěpána v Malíně stojí v dominantní poloze na nejvyšším místě někdejšího slavníkovského hradiště. Byl však v době gotiky pronikavě přestavěn, zanikla jeho apsida i celá jižní strana, proto jeho datování do 10. století není prokazatelné. Stávající stavba pochází z románského období, vznikla v polovině 12. století a podíleli se na ní sedlečtí cisterciáci. Zda byl kostel v té době nově postaven, nebo zda navazuje na starší stavbu, nelze za současného stavu poznání určit. 
Tento koncept tedy, zdá se, fungoval pro kostely zakládané v Kutné Hoře a jejím bezprostředním okolí ${ }^{41} \mathrm{v}$ průběhu 14. století, snad mohl zahrnout i některé starší kostely, ${ }^{42}$ ale ne všechny. ${ }^{43}$ Předpokládám, že jeho ideový záměr vznikl v prostředí Sedleckého kláštera, kde byla výstavba podle plánu podložena tradicí (plány klášterních areálů uchovávají antický koncept ideálního města) a ve spolupráci s horníky, kteří měli zkušenost s vyměřováním důlních polí. Vzhledem k tomu, že cisterciácký konventní kostel nebyl přístupný laické veřejnosti, přenášelo se podle cisterciáckého zvyku na kostely založené na pozemcích kláštera pouze jeho zasvěcení, ale faktickým východiskem městského plánu se stal farní kostel sv. Štěpána v Malíně. Domnívám se, že velikost opakujícího se modulu, podle kterého byla sít' městských kostelů rozvržena, je prakticky podložena násobkem nějaké konkrétní, v té době užívané, hornické metrické jednotky, jakou mohl být například později doložený horský lán $(15,4 \mathrm{~m}) .{ }^{44}$ O způsobu vyměřování vzdušných vzdáleností však zatím konkrétnější představu nemám.

Pokud horníci spojovali s výstavbou mariánských kostelů naděje na vytvoření vlastní městské duchovní správy, jejich záměry se v dané době nenaplnily. V roce 1354 byly na přímluvu Karla IV. důchody z kutnohorských kaplí vráceny malínské faře. Avšak v posledních letech vlády Karla IV. (†1378) a na počátku panování jeho syna Václava IV. nabyla v Kutné Hoře pevnějších obrysů úvaha o výstavbě nového posvátného okrsku s kostelem, hřbitovem, hřbitovní kaplí, školou a zvonicí, který by stál z dosahu Sedleckého kláštera. Horníci argumentovali potřebou vlastního hřbitova, aby v době, kdy jsou cesty do Malína a Sedlce nesjízdné, mohli pohřbívat (Čelakovský 1916). Z toho důvodu začali za hradbami města, na pozemku pražské kapituly, připravovat terén ke zbudování posvátného okrsku. Rychle rostoucí a houstnoucí osídlení Kutné Hory nedovolovalo založení hřbitova přímo ve městě, jak bylo ve středověku běžné, ale až za jeho hradbami. Proto byl nový okrsek samostatně opevněn a přičleněn do linie městských hradeb. To byla již aktivita třetí hornické generace, která získala pro své zakázky panovnickou stavební hut'. Pražská panovnická hut' v té době začala přestavovat Vlašský dvůr, kde si Lucemburkové v rámci mincovny zřizovali okázalou rezidenci. Byla to část svatovítské parléřovské huti, kterou v Kutné Hoře vedl Jan, syn stavitele svatovítské katedrály Petra Parléře. Nový posvátný okrsek měl formálně podléhat farní správě kostela sv. Václava v Pněvicích a pněvický farář měl přesídlit do Kutné Hory. V souvislosti se založením posvátného okrsku bylo ustanoveno (nejpozději v roce 1384) náboženské ,bratrstvo z Cechu“45, neboli cech písařů

41 Zmiňujeme se i o stavbách za hradbami města, ale mimo rozsah naší práce zůstaly kostel sv. Vavřince a kaple sv. Maří Magdaleny na Kaňku, které také podléhaly ve 14. století malínské farnosti.

42 Kostel Všech svatých.

43 Např. kostel sv. Jana Křtitele na dolním městě, na dnešním Jánském náměstí, zanikl v husitských válkách. Kostel sv. Jiří za Kouřimskou branou, který byl později začleněn do areálu jezuitské koleje.

44 Gustav Hofman, Metrologická příručka pro Čechy, Moravu a Slezsko do zavedení metrické soustavy, 1984).

45 Označení „,ech“ znamenalo důl a stavení k němu náležející. S rozvojem těžby nabývalo toto předměstí na významu a rostl počet tam usedlých obyvatel. K výstavbě nového kostela založili náboženské bratrstvo, které se označovalo podle místního názvu předměstí $\mathrm{Na}$ Cechu a bylo zasvěcené kultu Božího těla. 
- tedy těch, kteří pracovali jako královští nebo těžarští úředníci a žili na bohatém kutnohorském předměstí $\mathrm{Na}$ Cechu. Do bratrstva vstoupili i další horníci a zasvětili svou korporaci Božímu tělu. ${ }^{46}$ Šlo o v té době nově prosazovaný kult, který v Čechách propagoval arcibiskup Jan z Jenštejna a jenž povýšil na oficiální církevní svátek. Byla mu od roku 1382 zasvěcena kaple v Praze na Dobytčím trhu (Karlově náměstí). Arcibiskup inicioval založení bratrstva Božího těla př́i Sedleckém klášteře, kde nechal zř́́dit Boží hrob v kostele sv. Filipa a Jakuba ${ }^{47}$ a k němu i proslulou Sedleckou stř́ibrnou monstranci. ${ }^{48}$ Horníci chtěli soupeřit se sedleckými cisterciáky i v úctě $\mathrm{k}$ tomuto kultu a na místě, které navazovalo na významovou osu mezi malínskou farou a městem (a bylo tedy k sakrální funkci předurčeno už od počátku budování sítě městských svatyň), začali stavět katedrální kostel zasvěcený Božímu tělu a sv. Barboře ${ }^{49}$ Zasvěcení Tělu Božímu může být vnímáno jako rozvinutí a posunutí sedleckého mariánskému kultu - skrze Pannu Marii došlo ke Kristovu vtělení. Rozšíření patrocinia na kult sv. Barbory ${ }^{50}$ - patronku náhlé smrti (a tedy i havířù, kteří byli tomuto riziku každodenně vystaveni) - bylo zřejmě přáním korporace stavebníků a souviselo se snahou o založení vlastního městského hřbitova. Tak jak se bratrstvo a jeho prostředky k výstavbě kostela rozrůstaly, rostla i představa o rozsahu a nádheře staveb, především však nového kostela, který byl bez konkrétního církevního důvodu a potřeby koncipován jako trojlodní bazilika katedrálního typu s vysokým chórem lemovaným ochozem a věncem kaplí a s bočními předsíněmi, které měly nahradit příčnou lod'. Hlavní vstup byl orientován směrem k městu, nacházel se tedy na severní straně kostela. Jeho původní podobu neznáme. Užití katedrálního schématu nemělo církevní oprávnění, Kutná Hora nebyla v té době sídlem biskupa ${ }^{51}$ Byl to, zdá se, pouze výraz sebevědomí jeho objednavatelů, kteří zastupovali město jako celek a chtěli i v tomto ohledu soupeřit s cisterciáky a s královskou katedrálou sv. Víta.

Podle sedleckého vzoru vznikal i karner ${ }^{52}$ nového městského hřbitova. Měla to být patrová stavba, založená na čtvercovém půdorysu na skalnatém ostrohu ve svahu nad řekou.

46 Svátek Božího těla byl zaveden už v roce 1246 v lutyšské diecézi (Belgie) a bulou papeže Urbana I. od roku 1264 rozšířen v celé církvi. Je oslavou Kristova lidství i božství v „nejsvětější svátosti oltářní“. Jeho datum se odvozuje od velikonoc, slaví se ve čtvrtek po sv. Trojici. (Slovník judaismu, křest’anství, islámu, 1994, heslo: Boží tělo).

$47 \quad$ V té souvislosti dostavovala panovnická hut' ke starší lodi kostela lod' novou a v prostoru mezi jejich samostatnými chóry byl zřízen Boží hrob.

48 Sedlecká monstrance - věžovitá schránka na ukládání a veřejné vystavování hostie má podobu katedrálního chrámu, který je symbolickým př́ibytkem eucharistie. Ve svém ikonografickém programu zobrazuje Kristovo utrpení. Je stříbrná, pozlacená, vysoká 97 cm, vznikla k roku 1389 v pražské nebo horské parléřovské huti.

49 Zasvěcení chrámu Božímu tělu a zároveň patronce horníků sv. Barboře se uváděly až do 16. století, poté se používal pouze titul sv. Barbory.

50 Zatím pouze podle jezuity Jana Kořínka, nikoli podle dnes známých pramenů, navazovalo na zasvěcení starší hornické kapličky, která v místě kostela dřive stála.

51 Kutná Hora se stala dočasným sídlem utrakvistických biskupů až v pohusitském období. Hlavním kostelem utrakvistů byl horní mariánský kostel, v té době a souvislosti se změnil jeho titul, byl zasvěcen sv. Jakubovi Většímu.

52 Patrová hřbitovní kaple s kostnicí. 
Vystavěno bylo však jen spodní podlaží sloužící jako kostnice, horní kaple dostavěna nebyla. Architektura karneru byla koncipována jako trojvrstvý obraz kosmu stvořeného a ovládaného Bohem (podzemí, země, nebesa), ve kterém se odvíjí pozemský i posmrtný život člověka. Tuto představu měla zobrazit centrální stavba - proporčně v celku i detailu vyvážená, se dvěma nad sebou uspořádanými hmotově i významově vygradovanými prostory, které měly být diferencovaně osvětlené. $Z$ úrovně pozemského světa se ukládaly ostatky zemřelých do méně osvětleného podzemního prostoru kostnice, která byla místem čekání na Poslední soud. Světlem zcela naplněná měla jistě být zamýšlená kaple v patře, kde mělo dojít ke vzkříšení. V prostoru kostnice je kladen důraz na soulad dispozice, poměrů šířky a výšky prostoru i plnosti a oblosti architektonických článků a tento dojem byl dotvořen původní neutrální barevností tak, aby celý prostor měkce zářil světlem. Světlo je jediný dynamický prvek této místnosti, vstupuje v rovnoměrné hladině do zachovaného prostoru suterénu od východu rozměrnými okny a podle denní i roční doby postupně celé místo zalévá a pak z něj zas ustupuje (ve smrti jsou si všichni rovni).

Stavba chrámu Božího těla a sv. Barbory ${ }^{53}$ podle projektu pražské parléřovské huti byla zahájena na počátku osmdesátých let 14 . století v místě budoucího hlavního oltáře a obklopila starší kapli sv. Barbory, ${ }^{54}$ pokračovala výstavbou a klenutím ochozových kaplí a ochozu. Postupně dokončované kaple si zakupovali členové bratrstva z Cechu a jejich rodinní př́slušníci, od roku 1388 se postupně světily a uváděly do liturgické funkce. Avšak již v této první stavební etapě (před rokem 1396), byla koncepce změněna z bazilikálního trojlodí na pětilodí a zároveň bylo patrně také upuštěno od další výstavby karneru, protože síly objednavatelů a vykonávající hutě se soustředily na výstavbu rozsáhlého chrámu. To byla již pravděpodobně rozhodnutí nově nastupující čtvrté generace horníků. Hlavní oltář v provizorně zastřešeném chóru byl svěcen v roce 1391 a k roku 1396 byla vysvěcena i kaple patricijské rodiny Písků v prvních dvou polích jižní boční lodi. Na protější severní straně chrámu byla vystavěna v prvních dvou polích sakristie s pokladnicí v patře. Až do roku 1401 stavba chrámu pokračovala plynule, jeho liturgickou funkci zajištoval pněvický farář. Zároveň se začal použivat i hřbitov. Avšak v roce 1401 byla na žádost cisterciáků stavba pozastavena, aby se vyřešily problematické právní vztahy k malínské faře. Bratrstvo z Cechu se domohlo pokračování ve stavbě v roce 1403 a v roce 1410 papež Jan XXIII. povolil v Kutné Hoře zř́zení dvou samostatných farních obvodů. Farním kostelem se stal jak nově budovaný chrám Božího těla, tak i horní kostel Panny Marie. Ve stavbě kostela Božího těla se pokračovalo až do začátku husitských válek v roce 1419. Byly postaveny obvodové stěny a mezilodní pilíre. Popisovat a ve společenském kontextu interpretovat nedokončenou stavbu při této prríležitosti nepovažuji za vhodné. $V$ husitských válkách zaniklo i původní vybavení. Katedrální schéma bylo výsostným obrazem nebeského Jeruzaléma a umístění katedrály na vyvýšeném místě nad městem posvětilo celý obraz města. V roce 1437 císař Zikmund nařídil, že tento chrám zůstane vyhrazen katolickému ritu. Ostatní kostely města sloužily po husitských válkách utrakvistům. (V dalším pokračováním stavby mezi lety 1482 až 1548 a v doplňování jejího vybavení se pro Kutnou Horu ikonický význam tohoto chrámu

53 Prameny a plány soustředili Líbal, Zahradník a Macek (1996).

54 Byla zbořena jezuity až $\mathrm{v}$ roce 1626. 
zdůrazní a dále vystupňuje trojicí stanových stř̌ech v podobě plamenů. Bazilikální schéma se vestavbou tribun nad bočními dvoulodími změní na halu a završí krouženou klenbou, která ve stejné výšce zaklene všech pět lodí. U pilíř̊ tribun budou postaveny nové oltářní menzy, které ale už nebudou prodány a obsazeny).

Současně s výstavbou posvátného okrsku kolem kostela Božího těla a sv. Barbory dostavovala parléřovská hut' horní i dolní kostel Panny Marie a začala stavět špitální kostel sv. Kříže. I vybavení těchto kostelů v husitských válkách zaniklo.

\section{Závěr}

Nebylo mým cílem rekonstruovat historický obraz předhusitské Kutné Hory v jeho celistvosti. Zaujalo mne především rozvržení sakrálních staveb, které v té době vznikly, a „čtení“ jejich vztahů $\mathrm{v}$ urbanistickém obraze města, kterému přisuzuji význam estetický a zároveň ho vnímám jako obraz společnosti. Vycházím ze starší historiografie Kutné Hory, vlastní uměleckohistorické praxe a snažím se některá zjištění interpretovat nově ve světle kulturní antropologie.

Uvědomuji si, že „kamenný obraz“ Kutné Hory, který je dodnes patrný, nevypovídá tolik o každodenním životě, ale spíše o představách těch, kteří obraz města vědomě tvořili a využívali ho k vlastní osobní i stavovské reprezentaci i upevnění svých společenských a mocenských pozic a kteří s ním spojovali i naději na vlastní spásu. Urbanistický rozvrh a architektonické objekty, které jsem sledovala, vznikaly z vůle úzké patricijské skupiny v průběhu čtyř generací. Na základě písemných pramenů je obtížné přesně vysvětlit, proč báňští podnikatelé, horní a městští úrúedníci označovali sami sebe za horníky a co vše si za tímto pojmem představovali. Propojíme-li však chronologicky první uvedení názvu místa Hora s činností, která je s tímto pojmem obvykle spojována a která místnímu názvu předcházela i významem, jenž na tomto místě chtěli mít lidé sami sebe označující za horníky, vyplývá z toho, že tak vyjádřili vztah mezi prací, která se v hoře provádí (dolováním), i společností, která se při této práci utvořila a s činností a místem identifikovala. Tato skupina lidí se od patriciátu ostatních českých měst té doby odlišuje tím, jaký význam přikládala práci a místu, na kterém se práce provádí, a tím, že své profesní zaměření vnímala zároveň jako znaky svého společenského stavu a reprezentovala je v umění i politice - v kultuře města. Horníci při výstavbě svého města vystupovali jako korporace $\mathrm{s}$ kolektivní odpovědností nejen v praktickém životě, ale i v jeho symbolické rovině. Byli úzce spojeni s prostředím panovnického dvora i s patriciátem dalších báňských měst. Jejich první dvě generace spolupracovaly se sedleckými cisterciáky a s jejich pomocí vytvořily i začaly realizovat urbanistickou koncepci, která vtiskla městu odraz vyššího řádu a začlenila je (a spolu s ním i horníky) do vesmírného řádu, a tím vyjádřila i jejich společenské ambice. I když jejich potomci ve dvou následujících generacích vedli se sedleckými cisterciáky vleklý spor o patronátní právo $\mathrm{k}$ městským kostelům a kaplím a chtěli omezit jejich vliv na město a tím i podíl na jeho bohatství, neztratili ze zréetele „vesmírný“ aspekt urbanistického konceptu, ale naopak se ho zmocnili a príijali jej za výraz své suverenity a začali stavět městskou katedrálu bez církevně-právního zdůvodnění.

Pro vymezení a členění doby, kterou se zabývám, jsem zvolila koncept generací (30 let). „Krátkodobé změny si současníci dobře uvědomují, zatímco dlouhodobá změna je nepostižitelná v určitém čase, ale pozorovatelná v historickém pohledu, “ píše Burke (1996: 252). První generace v posledním desetiletí 13 . století se profilovala v úsilí vytvořit ze sídlišše město po právní a správ- 
ní stránce (pojmový obraz) a zřejmě v té době se začal vytvářet i koncept jeho urbanistického uspořádání (prostorový obraz). Následující tři generace horníků plynule navazovaly a přebíraly a stupňovaly představy svých předchůdců, jak posílit svo̊j význam zároveň s významem města. Na počátku 15. století se čtvrté generaci podařilo vymanit město z vlivu Sedleckého kláštera a jeho patronátního práva a překonat stavbou chrámu Božího těla a sv. Barbory i hřbitovního karneru i jeho kulturní význam. V době předpokládaného nástupu další generace však byl tento vývoj náhle zastaven husitskými válkami. Po nich byla Kutná Hora městem takřka zničeným, vypleněným, její báňské provozy byly načas uzavřeny. Poté se její společenská struktura vytvářela rychle znovu a s „novými horníky“ a za jiných okolností, i když stále ještě v gotickém duchu.

V souvislosti s realizací urbanistického konceptu jsem nově interpretovala zjištěné, pravidelně se v obraze města opakující prostorové vztahy mezi kutnohorskými městskými kostely, tedy modul cca 420 m, který je zjištěn jako vzdušná vzdálenost mezi kostelem sv. Jakuba a kostelem Panny Marie Na Náměti a dále se opakovaně projevuje i mezi dalšími městskými kostely. Autoři, kteří na tento modul upozornili a vykládali jej, jím potvrzují plánovitou výstavbu Kutné Hory a za jeho východisko považují shodně potvrzení kostela sv. Jakuba ve funkci hlavního městského kostela. Nepřihlížejí však k faktu, že kostel sv. Jakuba nese tento titul až od 15. století a že jeho původní patrocinium, Panně Marii, navazuje na zasvěcení sedleckého konventního kostela, a je tedy výrazem toho, že podnět k jeho založení vzešel z kláštera a že stavbu prováděla sedlecká stavební hut'. Stejně tak i další městský kostel Na Náměti nese mariáns ký titul a i na něm pracovala sedlecká hut’. Oba kostely vznikaly krátce po sobě, jsou oba filiálními kostely sv. Štěpána v Malíně, kde sídlil farář dosazený cisterciáky, a jsou co do významu rovnocenné. Opakování modulu $420 \mathrm{~m}$ mezi nimi nemůže tedy být podle mého mínění vyjádřením vztahu mezi hlavním městským kostelem (sv. Jakubem) a vedlejším městským kostelem. Domnívám se, že oba se stejnou měrou vztahují k farnímu kostelu v Malíně a hlásí se ke vzdušné (nebeské) a zároveň i chronologické linii mezi ním (je nejstarší), sedleckým konventním kostelem a městem. Kutná Hora se tak skrze své kostely zapojuje do dějin člověka v konkrétním místě, které tvoří úsek dějin spásy. Tímto způsobem se začíná vytvářet historia a fama města. Tuto významovou i časovou linku, která se vine od Sedlce proti toku řeky (!), pak na opačném konci města uzavírá chrám sv. Barbory, který ale už vzniká z vůle čtvrté generace horníků a vně sféry vlivu Sedleckého kláštera a v průběhu jehož výstavby se podaří prosadit vlastní městskou církevní správu. Některé další městské kostely je také několikanásobnou projekcí modulu možné vztáhnout k farnímu kostelu v Malíně a navíc ještě i kolmo k hlavní linii vedoucí proti proudu řeky. S určitou nadsázkou je možné uvažovat o sakrální paprsčité nebo pravoúhlé síti rozprostřené nad městem, ale činit z toho jednoznačné závěry zatím podle mého soudu nelze.

Uvědomuji si, že „čteni““ těchto obrazových pramenů může být zavádějící. Jsou abstraktní a jejich význam možná nebyl (a neměl ani být) zřejmý všem v době jejich vzniku, natož nám po takové době a v jiném kulturním kontextu. Vypovídají tedy jen o části městské společnosti a navíc jen o hodnotách, kterým jejich tvůrci přikládali trvalejší význam. Přesto - s vědomím všech úskalí - jde pro dobu, která po sobě nezanechala ucelenější soubor pramenů, o cennou inspiraci $\mathrm{k}$ úvahám.

Záměrně jsem k takové úvaze zvolila dobu postupného formování sídliště v město a jeho konsolidování, ve které bylo možné sledovat jen krátkodobé kulturní a společenské změny. Avšak právě ona usilovná snaha vtisknout chaotickému a rychle se rozrůstajícímu sídlišti urba- 
nistický rád musela mít ve středověku víc jak praktický význam. Doba, která tolik přála obrazům a vnímala je především jako zdroj poučení a odraz Božího světa v lidském, jistě přikládala symbolický význam i obrazu města a vztahu svátečního ke všednímu a části k celku. Město můžeme číst stejně jako sakrální architekturu, u které nás už interpretace jejího symbolického významu nepřekvapí. Kostel jako obraz světa a vesmíru, nebeského Jeruzaléma, symbol cesty, těla atd. se v odborné literatuře objevuje často, ale stejná stavba může být i vyjádřením představ o usporádání společnosti. Navíc stavba kostela ve městě je obraz v obraze, je to pars městského celku, jako je město pars světa a vesmíru. Ale stejně tak i středověké město mǔže být obrazem společnosti $\mathrm{v}$ jednotě obytné zástavby ve vztahu $\mathrm{k}$ radnici, městským hradbám a kostelům.

Předhusitská Kutná Hora je názorným př́kladem toho, proč a jak člověk město vytvárí a potřebuje. Chtěla bych také upozornit na, v té době patrný, souběžný vývoj slovesného obrazu města (místní názvy, právo, správa, dějiny apod.) a vizualizace v urbanistickém konceptu a architektuře. Jedno ovlivňuje druhé. Rozhodujícím uměleckým stylem, ve kterém byl obraz města ve 14 . století utvářen, byla gotika. Z jednoty tohoto stylu vyplývala formální jednota městského obrazu. „Gotika však nebyla jenom uměleckým slohem, nýbrž zahrnovala ideologii, životní způsoby, včetně stavebních typologií, řemeslnických pracovních postupů, stavebních materiálů, prostorových modulů určujících rozměry vnitřních a vnějších prostorů. Přes nesčíslné variace $\mathrm{v}$ jednotlivostech vedly tyto předpoklady $\mathrm{k}$ výraznému plastickému a jednotnému obrazu městské scény, posílenému navíc mocným kontrastem, jímž ve vztahu k řadové zástavbě působily dominantní veřejné budovy (chrámy, katedrály, hrady, opevnění, věže atd.)“ (Halík 1996: 12). Gotika vtiskla Kutné Hoře tak silný kulturní řád, že každá následující epocha s ním musela poměřovat svou vlastní stylovou sílu. Nakonec se uchovávání gotického, tedy původního charakteru města stalo více či méně programem každé další vlivné společenské složky, která rozhodovala o podobě a fungování města. Netýkalo se to pouze uchování výtvarných děl, tedy zhmotnělého obrazu města, ale i vytváření jeho pomyslného obrazu. Každá další epocha vývoje města se vztahovala ke středověké báňské minulosti, $\mathrm{k}$ jejím specifickým znakům, jakými mimo jiné bylo zvláštní zařazení a uspořádání městské společnosti ve feudálním kontextu, její silná vazba na prostředí královského dvora i $\mathrm{k}$ panovníkovi samému a mimořádná potřeba reprezentovat své postavení okázalými díly, ve kterých se projevil zvláštní vztah k prostoru a času, a tedy i k pozemskému životu v kontextu dějin spásy.

Při posuzování toho, jak a čím město vypovídá o společnosti, je třeba si uvědomit, kdo mohl v dané chvíli rozhodovat o jeho založení, rozvrhu či o konkrétní stavbě, o jejím uspořádání, vybavení apod. a s jakým záměrem. Do jaké míry je prvek, který pozorujeme, úplný nebo fragmentární. Jaký byl jeho původní kulturní kontext a jak se liší od toho dnešního, v jakém k němu přistupujeme my. Pro uchování hmotných obrazových pramenů je třeba pochopit (a ošetřit) nejen jejich materiální podstatu, ale i symbolický význam a jeho souvislosti. Naše poznání nikdy nebude definitivní, přesto bude důležité, protože se dále bude podílet na vytváření obrazu města. Ovlivní jeho trvání, zánik nebo porušení - změnu původního kontextu. Veškerá vědomá i nevědomá činnost (i nečinnost) člověka ve městě má svůj praktický dopad, protože město je stále živý obraz, je to trvalý prostorový lidský výtvor, který člověk zároveň vytváří, užívá, nazírá i interpretuje. Je to zatím nejsložitější dílo, které člověk ve své civilizaci a ke svému životu vytvořil a stále ještě tvoří. 


\section{Literatura}

Altová, B.; Pospíšil, A. 2000. „Kutná Hora a umění.“ In H. Štroblová, B. Altová (eds.). Kutná Hora. Praha: Nakladatelství Lidové noviny, s. 297-325.

Bažant, J. 2000. Uměni českého středověku a antika. Praha: Koniasch Latin Press.

Brandi, C. 2000. Teorie restaurování. Kutná Hora: Tichá Byzanc [1977, Einaudi: Torino].

Burke, P. 1996. Italská renesance. Kultura a společnost v Itálii. Praha: Mladá fronta.

Čelakovský, J. 1916. „Klášter sedlecký, jeho statky a práva v době před válkami husitskými.“ Rozpravy, tř́ida 1, číslo 58, Praha.

Halík, P. 1996. „Počátky a proměny současné urbanistické scény.“ In P. Halík, P. Kratochvíl, O. Nový Architektura a město. Praha: Academia.

Halík, P.; Kratochvíl, P.; Nový, O. 1996. Architektura a město. Praha: Academia.

Handiaková, E. 1958. Hlavní období urbanistického vývoje města Kutná Hora. Kutná Hora.

Herout, J. 1949. „Středověký půdorys a opevnění Kutné Hory.“ Zprávy památkové péče, 9: 49-67.

Hofman, G. 1984. Metrologická príručka pro Čechy, Moravu a Slezsko do zavedení metrické soustavy. Praha

Kořínek, J. 2000 [1675]. Staré paměti kutnohorské. A. Stich, R. Lunga (edice, komentář a interpretace). Praha: Nakladatelství Lidové noviny.

Kratochvíl, P. 1996. „Město jako kulturní fenomén.“ In P. Halík, P. Kratochvíl, O. Nový Architektura a město. Praha: Academia.

Kronika Zbraslavská, Chronicon Aulae Regiae. 1952. Z latiny přeložili F. Heřmanský, A. Paulů, R. Mertlík, historický komentár Z. Fiala. Praha.

Kruml, M. 1991. „O obrazu města na př́íkladu Kutné Hory“. Tradition und Zukunft, Band 4. Vídeň: Institut für Baukunst und Bauaufnahmen, Technische Universität Wien.

Leminger, E. 1924. „Hodiny na věži radniční.“ Kutnohorské př́spěvky $k$ dějinám vzdělanosti české, 2, sešit 2: 81-83.

Leminger, E. 1927. „Stavební vývoj staré Kutné Hory, její ulice a tržiště.“ Kutnohorské př̌spěvky ke vzdělanosti české, 3, sešit 1-4: 64-70.

Líbal, D.; Heroutová, M. 1961. Kutná Hora, průvodní zpráva ke stavebnè-historickému průzkumu městského historického jádra. Praha: SÚRPMO.

Líbal, D.; Zahradník, P.; Macek, P. 1996. Kutná Hora, Chrám sv. P. Barbory, př́pravná etapa pri̊zkumu. Praha: MURUS (rukopis).

Lynch, K. 2004. Obraz města. Bova Polygon: Praha [1960 MIT and the President and Fellows of Harvard College].

Matějková, E. 1962. Kutná Hora. Praha: SNKLHU.

Matějková, E. 1969. „Sankturinovský dům, historický význam a dnešní využití.“ Krásné město, číslo 2: 11-12; 3: 13-14; 4: 9-12.

Muk, J.; Lancinger, L. 1985. Vlašský dvůr. Stavebně-historický průzkum. Praha: SÚRPMO (strojopis).

Norberg-Schulz, Ch.1994. Genius loci. Praha: Odeon.

Nový biblický slovnik. 1996. Návrat domů: Praha. Přeloženo z anglického originálu New Bible Dictionary. Inter-Varsity Fellowship 1962, second revised edition 1982, s. 221, heslo „Eschatologie". 
Rossiaud, J. 1997. „Měšt’an a život ve městě.“ In Le Goff (ed.) Středověký člověk a jeho svět. Praha: Vyšehrad.

Sokol, J. 2004. Člověk a náboženství. Proměny vztahu člověka k posvátnému. Praha: Portál.

Štroblová, H.; Altová. B. (eds.). 2000. Kutná Hora. Praha: Nakladatelství Lidové noviny.

Vavák, F. J. 1918 [1800]. Paměti, díl 3, Skopec, F. (ed.): Praha, s. 96-99.

Vinař, J. 2004. Kutná Hora: dlažby v historickém jádru. Průzkum historického stavu. MURUS (strojopis).

Zach, J. 1882. „Chrám Matky Boží na Náměti v Hoře Kutné.“ Roční zpráva c. $k$. vy̌šsich reálných škol a reálného gymnasia v Hoře Kutné, s. 3-29.

\section{Autorka}

Blanka Altová absolvovala FF UK v Praze, obory historie a dějiny umění. Působila v Oblastním muzeu v Kutné Hoře, v Ústavu dějin umění AV ČR v Praze a na Institutu restaurování a konzervačních technik v Litomyšli. Autorsky a editorsky se podílela na vydání knihy Kutná Hora v Nakladatelství Lidové noviny (2000). Nyní je odbornou asistentkou v historickém modulu a zároveň doktorandkou katedry obecné antropologie na FHS UK v Praze. Kontakt: altovabl@gmail.com 